Agriculture

Research Direction générale

Branch de la recherche

Technical Bulletin 1987-14E

Yield and quality of seven grass species at seven locations in the Central Interior of British Columbia 



\section{Yield and quality of seven grass species at seven locations in the Central Interior of British Columbia}

KLAAS BROERSMA

Agriculture Canada

Experimental Farm

Prince George, B.C.

IIM N. TINGLE

Field Crops Branch

B.C. Ministry of Agriculture and Fisheries

Prince George, B.C.

Technical Bulletin 1987-14E

Research Branch

Agriculture Canada

1987 
Copies of this publication are available from Superintendent

Experimental Farm

Research Branch, Agriculture Canada

R.R. 8, Rmd No. 6

Prince George, B.C.

V2N 4M6

Produced by Research Program Service

(C) Minister of Supply and Services Canada 1987

Cat. No.: A54-8/1987-14E

ISBN: $0-662-15464-9$

The dots on the map represent Agriculture Canada research establishments. 


\section{ABSTRACT}

Yield and chemical composition parameters were determined for seven grass species at seven locations throughout the Central Interior of B.C. The seven grass species included smooth brome, crested wheat, timothy, reed canary, meadow foxtail, creeping red fescue and intermediate wheat. The locations included two sites at Smithers, one each at Grassy Plains, Vanderhoof, Prince George, MCBride and Williams Lake. Parameters determined were dry matter yield, in vivo digestibility, crude protein, phosphorus, calcium, potassium, magnesium, manganese, copper and zinc. Also calculated were digestible dry matter yield, crude protein yield and the calcium to phosphorus ratio.

\section{RÉSUMÉ}

On a défini les paramètres du rendement et de la composition chimique de sept espèces de graminées cultivées dans sept endroits du Centre intérieur de la Colombie-Britannique. Les espèces examinées étaient le brome inerme, l'agropyre à crête, la fléole, l'alpiste roseau, le vulpin des prés, la fétuque rouge traçante et l'agropyre intermédiaire. Deux des emplacements d'essais étaient à Smithers, les autres se répartissant entre Grassy Plains (1), Vanderhoof (1), Prince George (1), McBride (1) et Williams Lake (1). Les paramètres étudiés comprenaient le rendement de matière sèche, la digestibilité in vivo, les teneurs en phosphore, calcium, potassium, magnésium, manganèse, cuivre et zinc. On a aussi calculé le rendement de matière sèche digestible, le rendement de protéine brute et le rapport calcium: phosphore. 
TABLE OF CONTENTS

\section{ABSTRACT/RESUME}

TABLE OF CONTENTS

List of Tables

iii

List of Figures

iv

Acknowledgements

iv

INTRODUCTION

Climate

Soils and It's Landscape

The Test

RESULTS

Smithers \#1

Smithers \#2

Grassy Plains

Vanderhoof

Prince George

McBride

Williams Lake

Location Averages

23

Species Averages

A. Notations Used.

B. Conversion Factors for English and Metric Units.

C1 Dry matter yield rankings of the seven grass. species at each location.

C2 Percent digestible dry matter rankings for seven grass species at each location.

C3 Percent crude protein rankings for the seven grass species at each location. 


\section{List of Tables}

Table 1. Geographical and selected soil characteristics of the seven test sites.

Table 2. The grass species used and some of their descriptive characteristics.

Table 3. Selected climatic parameters for the seven test sites from nearby long-term meteorological records.

Table 4. Average yield and chemical composition data of the seven selected grass species. Smithers \#1.

Table 5. Average yield and chemical composition data of the seven selected grass species. Smithers \#2.

Table 6. Average yield and chemical composition data of the seven selected grass species. Grassy Plains.

Table 7. Average yield and chemical composition data of the seven selected grass species. Vanderhoof.

Table 8. Average yield and chemical composition data of the seven selected grass species. Prince George.

Table 9. Average yield and chemical composition data of the seven selected grass species. McBride.

Table 10. Average yield and chemical composition data of the seven selected grass species. Williams Lake.

Table 11. Average yield and chemical composition data of all seven selected grass species at each of the seven locations.

Table 12. Average yield and chemical composition data of the seven selected grass species for all the seven locations.

Table 13. The average content of $\mathrm{Mg}, \mathrm{Mn}, \mathrm{Ca}$ and $\mathrm{Zn}$ for seven selected grass species and for the seven locations. 
List of Figures

Page \#

Figure 1. Map of British Columbia and the location of the test sites throughout the Central

Interior.

Figure 2. Average total monthly precipitation(mm) for the test sites from nearby long-term

meteorological records.

Figure 3. Average days of frost for the months of the growing season from nearby long-term meteorological records.

\section{Acknowledgements}

We thank Mrs. Ann Robertson and Ms. Sandra Kinsey for typing of the text and tables and Mr. Arthur Yee for preparing two of the figures. We also would like to thank $\mathrm{Mr}$. W.L.Pringle and Dr.J.A. (AI) Robertson for editing the manuscript. 


\section{INTRODUCTION}

Agriculture in the Central Interior of British Columbia is primarily a forage based livestock industry. This makes the growing of forage crops important. Studies at the Prince George Experimental Farm have shown that grasses in general are better adapted for growing in many areas than legumes because of unfavourable soil and climatic conditions. These conditions vary with location because of the diversity experienced

throughout the Central Interior of B.C. The growth of several species of grasses were studied at seven locations to determine their growth habits, yield potential, and chemical composition.

The seven locations selected cover a significant portion of the agricultural areas of the Central Interior of B.C., as well as many of the major soil types. The locations, with the exception of Williams Lake, are located on a roughly east-west line, with McBride $200 \mathrm{~km}$ east and smithers $400 \mathrm{~km}$ to the west of Prince George. Williams Lake is located $250 \mathrm{~km}$ to the south. Site locations and selected soil characteristics are described in Table 1 and Figure 1.

The grass species tested consisted of a group that included grasses suitable for a wide variety of soil and climatic conditions. The species and cultivars employed and comments on their adaptation characteristics are listed in Table 2. The grasses, in general, are relatively winter hardy but vary in their ability to withstand soil moisture conditions. Reed canary grass, meadow foxtail, and timothy are all able to withstand poorly drained soils. The remaining four grasses: smooth brome grass, crested wheat grass, creeping red fescue, and intermediate wheat grass are better adapted to well-drained soil conditions and are able to withstand a wider range of drought tolerance. In this publication, the grasses will be referred to by common species name only, but will reflect the varieties that are recommended and grown in this area. varietal differences are known to occur due to climate and location, but were not accounted for in this study. The varieties consisted of Carlton smooth brome grass, summit crested wheat grass, Climax timothy, Frontier reed canary grass, Canada \#1 meadow foxtail, Boreal creeping red fescue, and Chief intermediate wheat grass (Table 2).

\section{Climate}

The fact that temperature decreases and precipitation increases with increasing elevation is well known. In B.C., with its mountainous terrain, these relationships are not simple. In mountain valleys, temperature inversions are common 


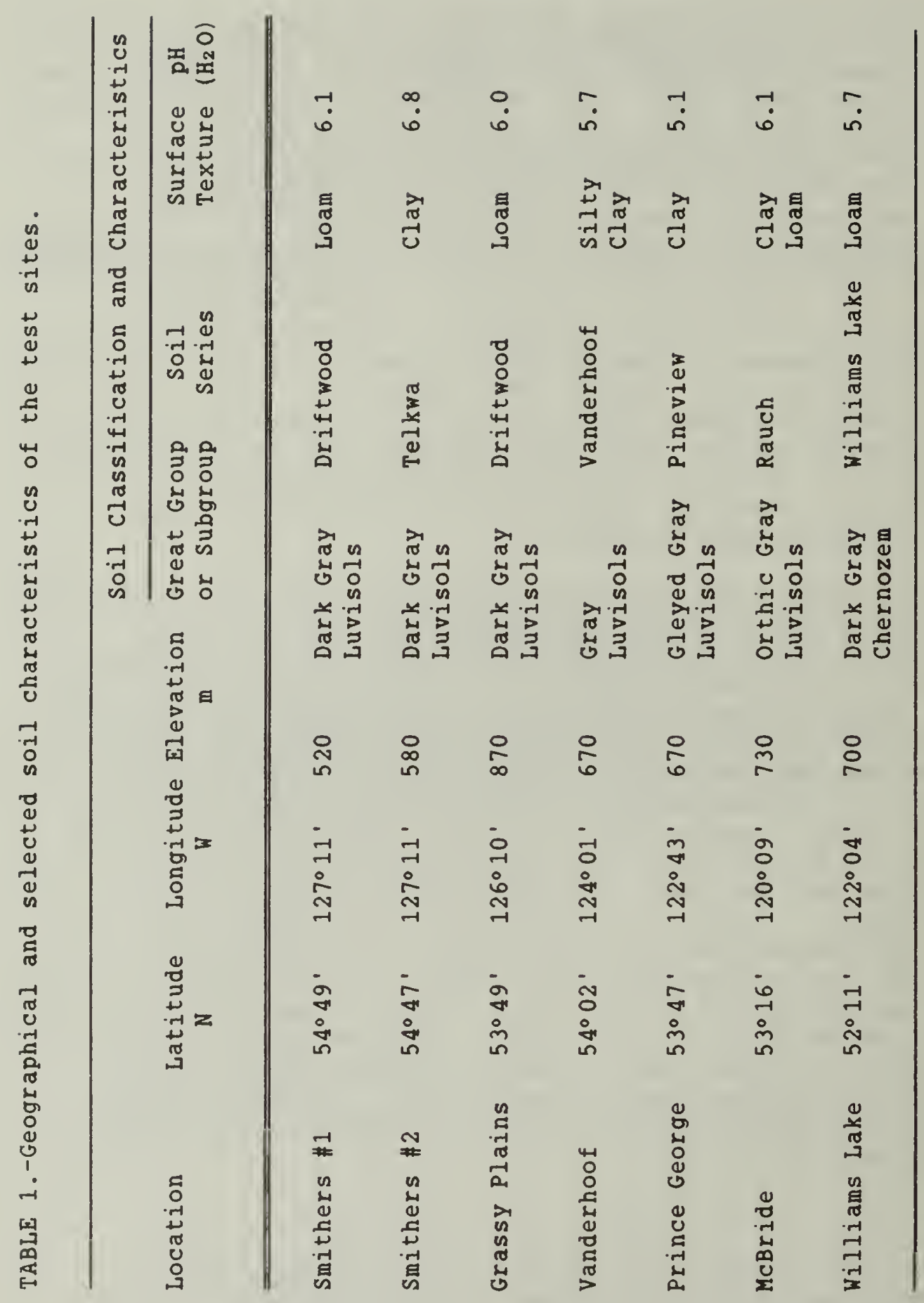




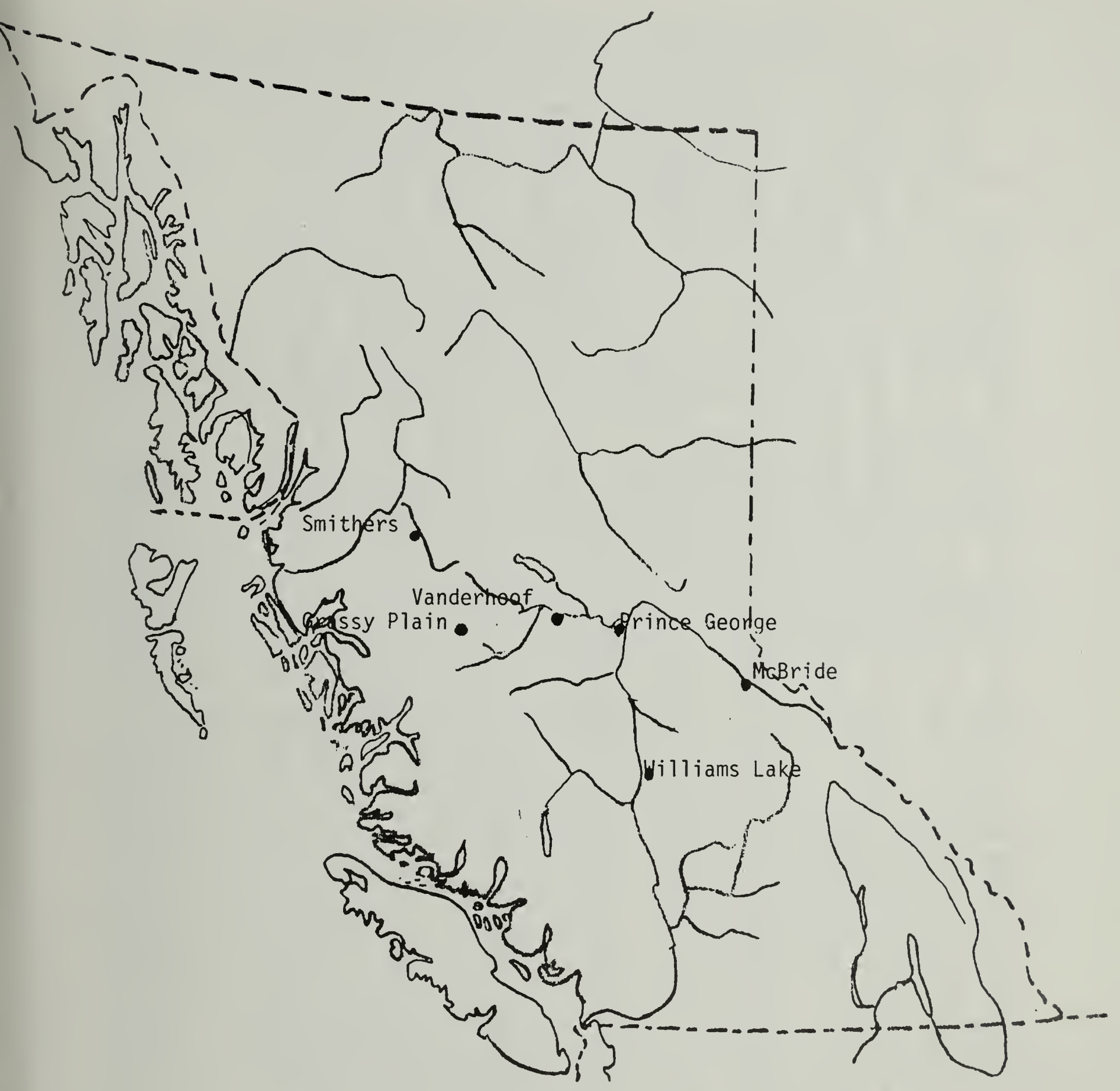

Figure 1. Map of British Columbia and the location of the test sites throughout the Central Interior. 


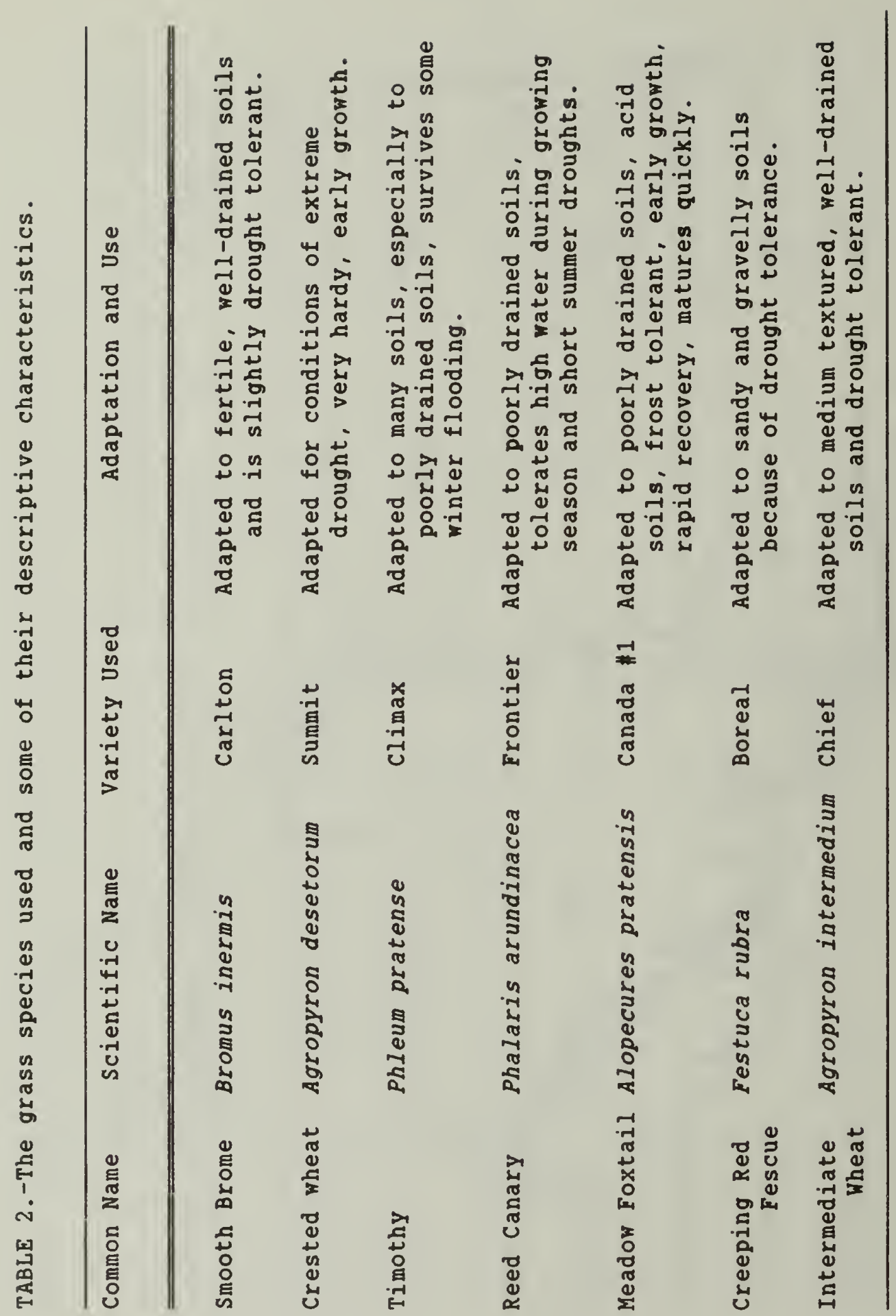


and cause the temperature to depart from the normal of surrounding areas. The effect of mountains in the prevailing storm paths cause more precipitation to fall on the windward side. In the lee of these obstructions a rain shadow, or reduced zone of precipitation, is produced. It is thus the influence of topography, elevation, and location within the landscape that causes much of the differences in climate at each site. The climate of the central Interior of B.C. can be described as continental as much of the influence of the Pacific Ocean is lost by the Coast Mountains acting as a barrier. In general, the summers are warm and the winters long and cold. Precipitation is light to medium $(400-750 \mathrm{~mm})$ and fairly evenly distributed throughout the year(Table 3). The actual climatic conditions experienced at any one locale can be quite different from nearby long-term climatic stations because of the effects of rugged terrain causing many micro-climates.

The temperature for the sites on the Nechako Plateau and Nechako Plain (Smithers, Grassy Plains, Vanderhoof, Prince George) are very similar with Grassy Plains having the lowest mean temperature. These lower temperatures are a reflection of the higher elevation. McBride and Williams Lake have the highest mean annual temperature. The lowest mean maximum temperatures have been recorded at Grassy Plains and the lowest mean minimum temperature at Vanderhoof. Temperatures during the normal growing season, May to september, follow a similar trend to mean annual temperatures at these locations.

The precipitation and its pattern show, in general, an even distribution with a decline in the months from February to May, inclusive, which is characteristic for the area. The total precipitation ranges from $402 \mathrm{~mm}$ at Williams Lake to $621 \mathrm{~mm}$ at Prince George. Snowfall accounts for about $40 \%$ of the total precipitation while roughly another 40\% falls during the growing season, May to september. At Prince George and Williams Lake the growing season precipitation is higher at 46 and $51 \%$ of the total precipitation, respectively. The water deficit during the growing season depends on the precipitation supplied during the growing season, on temperature, and on the ability of the soil to store water that is available to the plants. The higher temperatures, coarser textured soils, and lower precipitation areas usually experience greater water deficits. In this area, moisture deficits usually occur from mid-June to the beginning of July when soil moisture becomes depleted and the crops become dependent on the current precipitation or irrigation.

The growing season varies from 94 to 121 days with Vanderhoof having the shortest season. In most cases, the last day of killing frost $\left(\leq 2^{\circ} \mathrm{C}\right)$ usually occurs at the end of May, except for Vanderhoof where it is the first week of June. The 


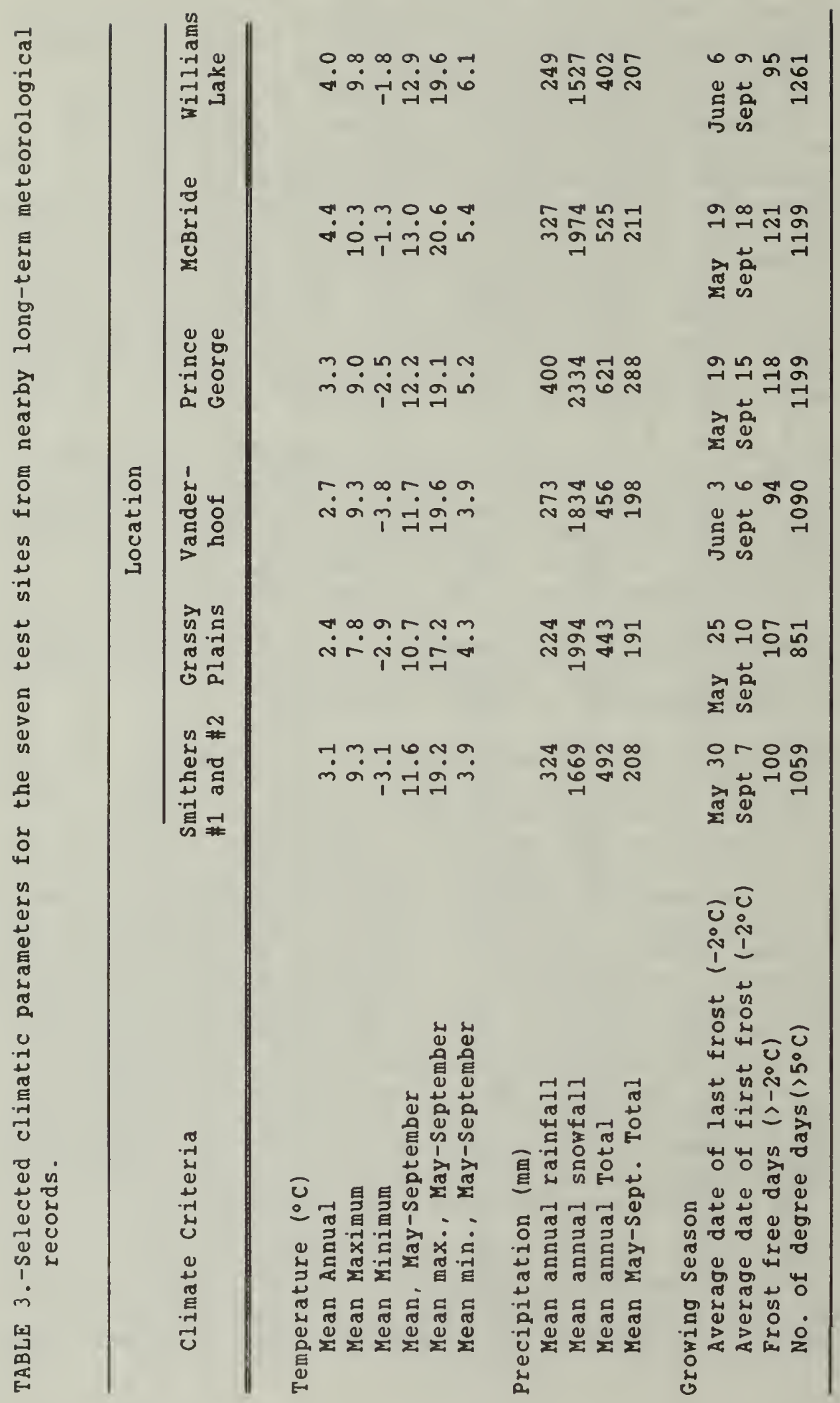




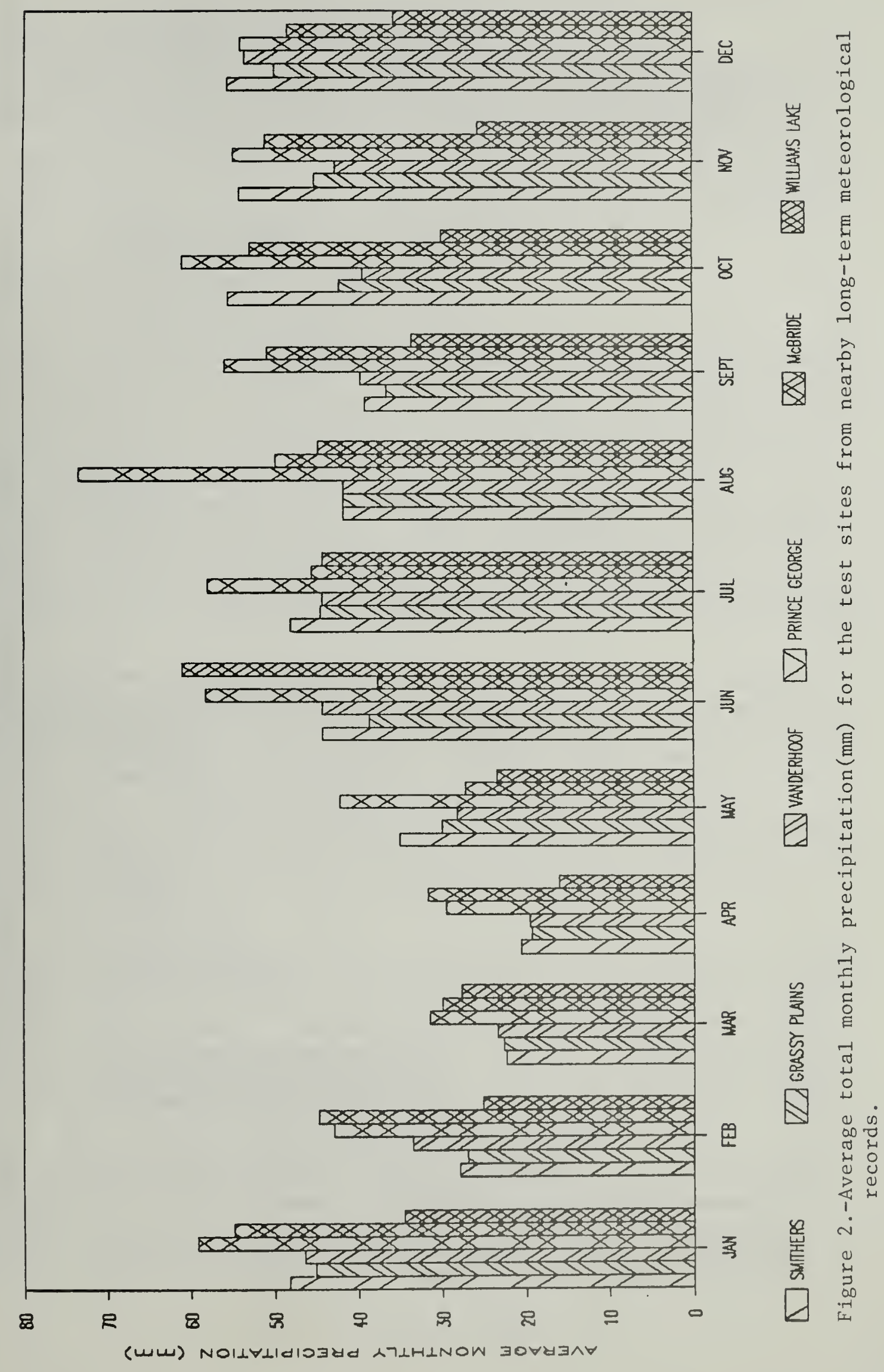




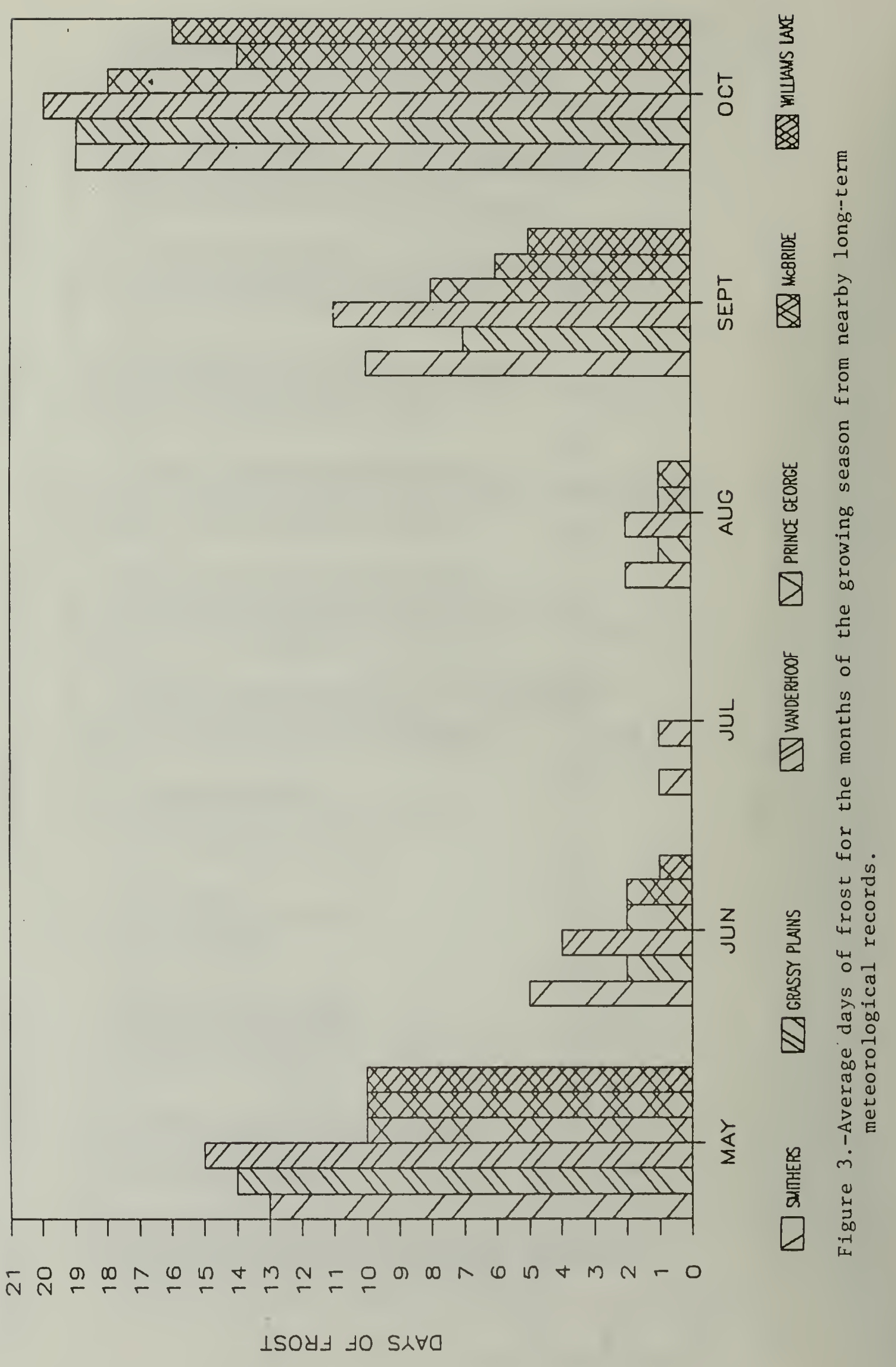


first day of a killing frost in the fall occurs about mid-September. The number of degree-days accumulated 1100 per year, except for the higher elevations where maximum and minimum teperatures are lower, especially in the growing season. This is experienced at a site such as Grassy Plains. It is apparent from Figure 3 that there is a chance of frost in every month except July. In fact, every few years the smithers and Vanderhoof sites do experience a frost in July, although this is usually not a severe killing frost.

\section{Soils and Its Landscape}

The main area of the central Interior of B.C. is made up of the Nechako Plateau and the Nechako Plain, with McBride situated in the Rocky Mountain Trench. The topography of the interior plateau consist of large rolling upland areas separated by broad valleys. The area was glaciated and is covered by a glacial deposit which has been modified by subsequent erosion and laking. Coarse materials were deposited by the glacial meltwaters before reaching the lakes. The largest lacustrine basins are found around Fort st. James, Vanderhoof, and Prince George. This has resulted in soils of varying texture and drainage, with soils developed on lacustrine materials being heavy textured and soils developed on outwash being gravelly and lighter textured.

The soils in the Central Interior of B.C. plateau consist mainly of Gray Luvisols. The native forest vegetation adds little organic matter into the soil and the litter layer is thin and poorly decomposed. The surface mineral layer under the litter layer is usually leached and light in colour with a very weak structure. The soil horizon below this is much finer in texture because of clay accumulation which has a strong angular blocky structure that resists root proliferation and water percolation. In spring, these soils are wet because of this restrictive layer.

The soils that develop on the coarser parent material of the glacial outwash are mainly of the Brunisolic soil order. These soils are coarser and have a lower water holding capacity and usually are less fertile. Other coarse soils found along major streams are often of the Regosolic soil order in that there is little soil development of the original parent material. These soils are developed from alluvial materials and are often very fertile.

Near Quesnel and Williams Lake Chernozemic soils developed on the grasslands can be found which have an accumulation of organic matter in the surface horizon. These soils, are not extensively leached. Dark Gray Chernozemic soils are found in a transition zone between the grassland and the forest soils. 


\section{The Test}

The test was sown in the spring of the years 1969,1970 , and 1971 at each location(Figure 1) and harvested for three consecutive years following seeding. The 1970 seeeding at McBride failed to establish, therefore only the 1969 and 1971 seedings are reported for that site. Fertilizer was top dressed each spring to assure adequate available nutrients at rates of $84,112,56,27, \mathrm{~kg} / \mathrm{ha}$ of nitrogen $(\mathrm{N})$, phosphorus $\left(\mathrm{P}_{2} \mathrm{O}_{5}\right)$, potassium( $\left.\mathrm{K}_{2} \mathrm{O}\right)$, and sulfur(S), respectively. The plots were harvested mechanically with a swift Current flail harvester. The aim was to harvest at the early heading stage. Due to travelling distances, stage of harvest varied between early heading and anthesis. The total harvest included the first cut and aftermath, if any was present, and was reported as dry matter(DM) yield. The quality of the first cut only was determined by analyzing for crude protein(CP) by macro-Kjeldahl, in vivo digestible dry matter(DDM), and mineral content other than phosphorus(P) by spectroscopy. The mineral analysis included potassium(K), calcium(Ca), magnesium(Mg), manganese $(M n), \quad z i n c(Z n)$, and copper $(C u)$. Phosphorus(P) was determined by ashing and colorimetry. Digestible dry matter(DDM) yield was calculated from the product of DM yield by rDDM. Crude protein yield was calculated from the product of DM yield by $\%$ CP. The results presented were the averages of three consecutive seeding years, each harvested for three years, giving a total of nine harvest years, except for McBride which had only six harvest years because of establishment failure in 1970 .

\section{RESULTS}

\section{Smithers \#1 (Table 4 )}

Yields of DM for the seven grass species ranged from 5200 to $8400 \mathrm{~kg} / \mathrm{ha}$ at the smithers \#1 location. The highest DM yield was from reed canary grass and the lowest from meadow foxtail. The DDM ranked differently from the DM yield with the highest yield, reed canary grass, having the lowest DDM of 53.8\%. The lowest yielding species, meadow foxtail, had the highest DDM of 73.2\% a difference of nearly 20\%DDM between the two species. The remaining five species ranged from 59.2 to $62.8 \% D D M$ with an average of $61.2 \%$. Expressed as DDM yield in $\mathrm{kg} / \mathrm{ha}$ timothy ranked first, smooth brome grass second, and intermediate wheat grass third.

Crude protein ranged from 8.9 to $16.5 \%$ for the seven different species. The $16.5 \%$ CP of the meadow foxtail was considerably higher than the $12.2 \%$ for crested wheat grass the 


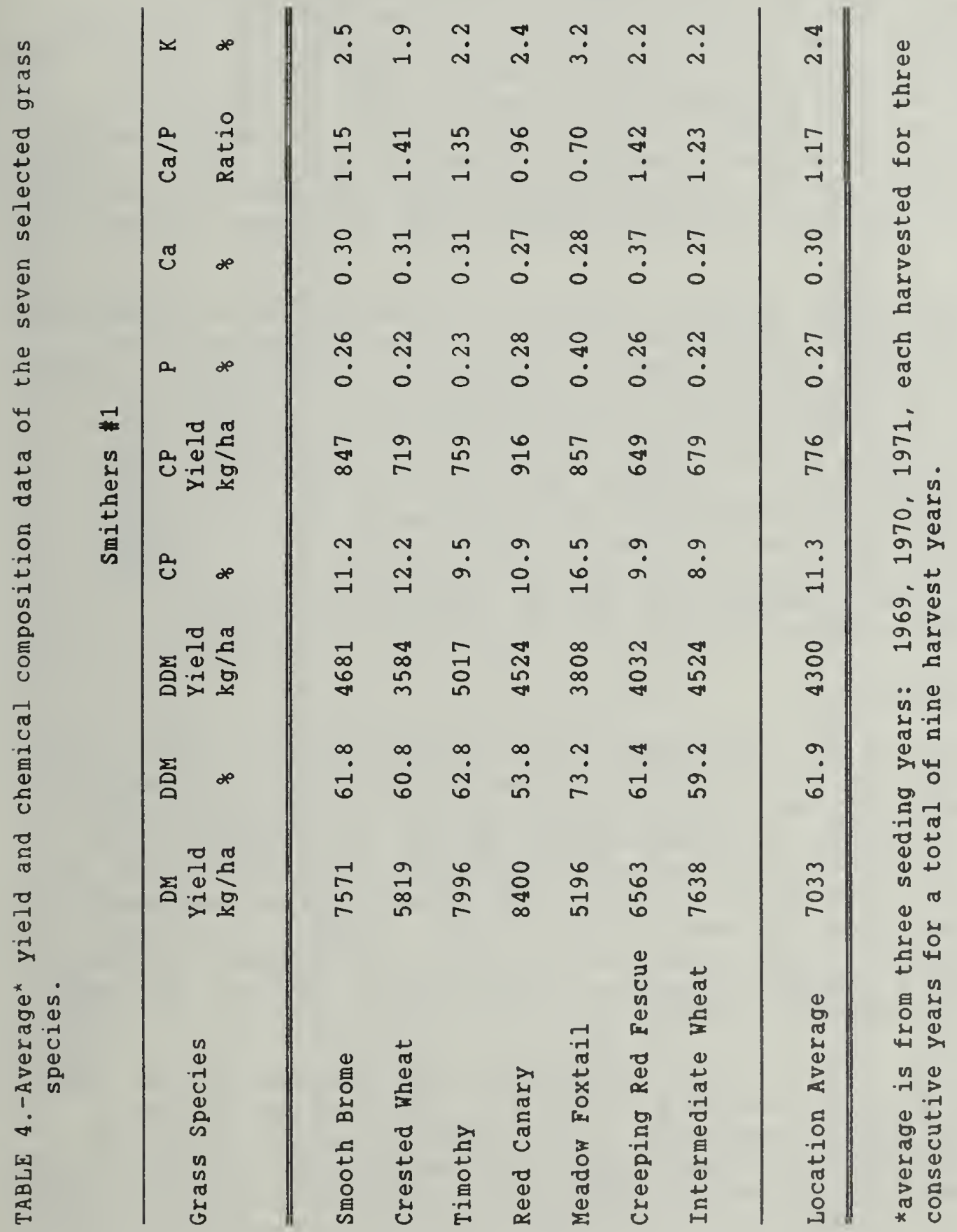


next highest. The lowest $\% C P$ was for the intermediate wheat grass. Reed canary grass produced the highest yield of CP/ha at $916 \mathrm{~kg}$ followed by meadow foxtail and smooth brome grass. The remaining five species ranged from 649 to $759 \mathrm{~kg} / \mathrm{ha} \mathrm{CP}$.

Meadow foxtail had the highest $P$ content which was significantly greater than that of the other species. Calcium content ranged from 0.27 to $0.37 \%$ with creeping red fescue being the highest. Calcium to $\mathrm{P}$ ratios ranged from 0.70 to 1.42 , which reflects the extremes of $\mathrm{Ca}$ and $\mathrm{P}$ content. The lowest Ca/P ratio was for meadow foxtail because of its high $P$ uptake and the highest was for creeping red fescue which was due to its high Ca uptake. Meadow foxtail also had the highest $\mathrm{K}$ content of over $3 \%$ while the remaining species had $K$ content between 1.9 and $2.5 \%$.

Micro-nutrients for the Smithers \#1 location were summarized but not tabulated. Magnesium content of the grass species varied from $0.07 \%$ for the wheat grasses to $0.17 \%$ for reed canary grass with an average of $0.11 \%$. Average $M n$ for the seven species was $56.3 \mathrm{\mu g} / \mathrm{g}$ with crested wheat grass having the lowest $\mathrm{Mg}$ content of $29.5 \mu \mathrm{g} / \mathrm{g}$ and creeping red fescue the highest with $96.9 \mu \mathrm{\mu g} / \mathrm{g}$. Copper levels in the grasses ranged from $2.9 \mathrm{\mu g} / \mathrm{g}$ for intermediate wheat grass to $5.5 \mathrm{\mu g} / \mathrm{g}$ for meadow foxtail with an average for all species of $3.9 \mu \mathrm{g} / \mathrm{g}$. Zinc contents were from 22.3 and $22.6 \mathrm{\mu g} / \mathrm{g}$ for intermediate wheat grass and creeping red fescue, respectively, to $42.5 \mathrm{\mu g} / \mathrm{g}$ for meadow foxtail.

\section{Smithers \#2 (Table 5)}

Yields of DM at the smithers \#2 location ranged from a low of $4144 \mathrm{~kg} / \mathrm{ha}$ for crested wheat grass to a high of $7952 \mathrm{~kg} / \mathrm{ha}$ for reed canary grass. The overall average for this location for the seven grass species was $6428 \mathrm{~kg} / \mathrm{ha}$. The $\%$ DDM varied from 56.6 to $68.4 \%$ with reed canary grass having the lowest and meadow foxtail the highest $\% D D M$. The other species averaged $61.2 \%$ DDM and were all very close to this average. The DDM yield resulted in reed canary grass being the highest with 4502 $\mathrm{kg} / \mathrm{ha}$ DDM even though it had the lowest rDDM, and was followed closely by intermediate wheat grass and timothy.

Percent CP for all seven grass species averaged 11.4\%. The highest $\%$ CP was for meadow foxtail with $15 \%$ and the lowest, intermediate wheat grass with $8.7 \%$. Determination of the CP yield shows that reed canary grass had the highest CP yield of $954 \mathrm{~kg} / \mathrm{ha}$ and crested wheat grass the lowest because of its low DM yield. The remainder of the species ranged from 658 to 789 $\mathrm{kg} / \mathrm{ha} \mathrm{CP}$. 


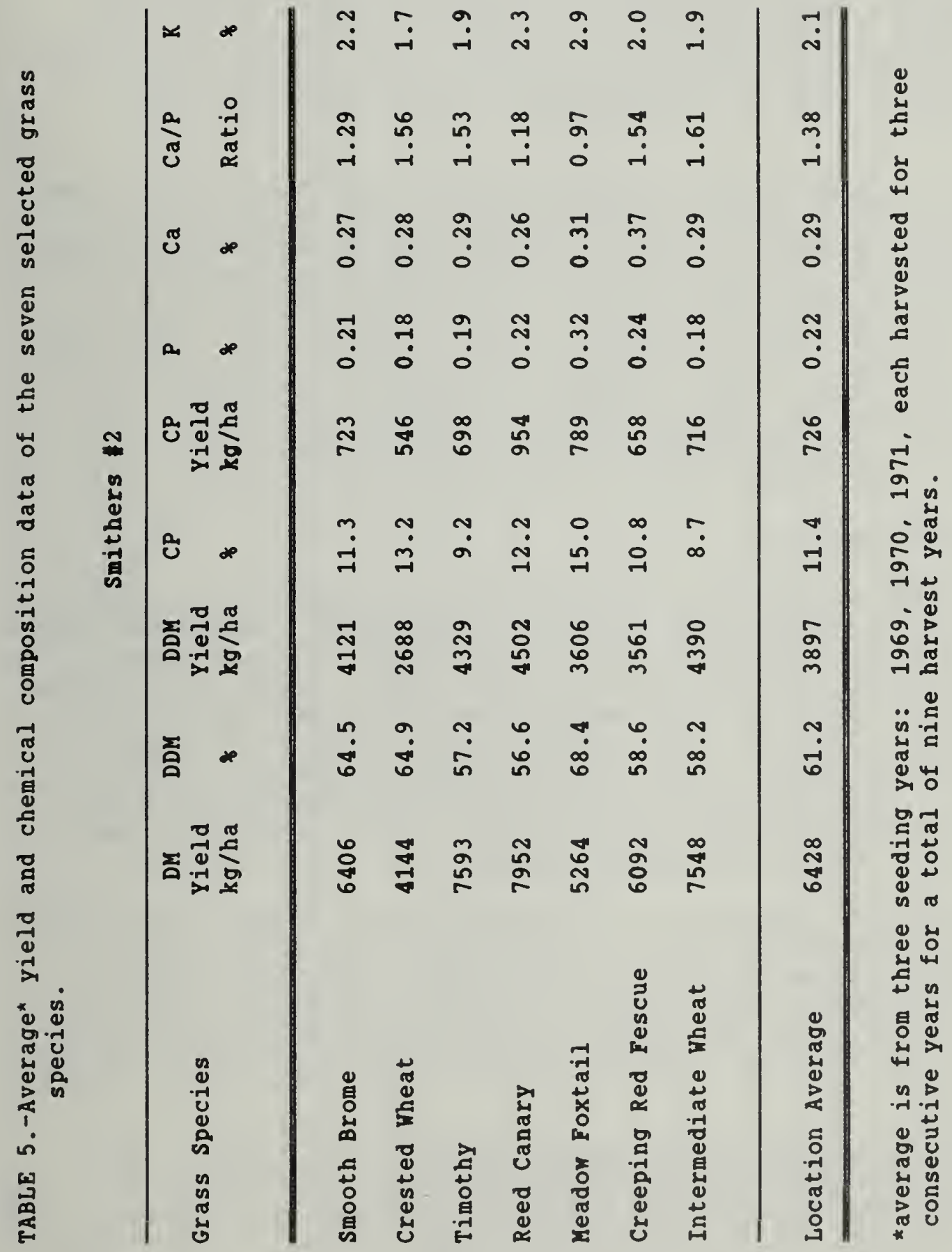


Phosphorus level in the forage ranged from 0.18 to $0.32 \%$, with the wheat grasses having the lowest, and meadow foxtail the highest content. Calcium contents averaged $0.29 \%$ with creeping red fescue having the highest level. All other species were similar. The Ca/P ratios were all above 1, except for the meadow foxtail which tended to accumulate more $P$ than other species while having average Ca uptake. Potassium levels were above $2 \%$, with only the wheat grasses having levels below $2 \%$. Meadow foxtail took up considerably more $R$ than the other species.

Micro-nutrient levels for $\mathrm{Mg}, \mathrm{Mn}, \mathrm{Cu}$, and $\mathrm{Zn}$ have not been tabulated. The Mg levels ranged from 0.09 to $0.18 \%$ with the wheat grasses having the lowest levels, while reed canary grass had the highest. The average $M n$ content for the seven grass species was $28 \mu \mathrm{g} / \mathrm{g}$, with crested wheat grass having the lowest $\mathrm{Mn}$ content of $12.6 \mathrm{\mu g} / \mathrm{g}$. Copper levels had a range of 3.0 to $6.9 \mu \mathrm{g} / \mathrm{g}$, with intermediate wheat grass being the only one below $4.0 \mathrm{\mu g} / \mathrm{g}$. Zinc content averaged $23.6 \mathrm{\mu g} / \mathrm{g}$. The lowest level was in the intermediate wheat grass, with $17.1 \mu \mathrm{g} / \mathrm{g} \mathrm{Zn}$, and the highest was in meadow foxtail at $34.2 \mathrm{\mu g} / \mathrm{g}$. All others were in the 20-25 $\mathrm{\mu g} / \mathrm{g} \mathrm{Zn}$ range.

\section{Grassy Plains (Table 6)}

The yields of DM for Grassy Plains are presented in Table 6. The yields ranged from a low of $3875 \mathrm{~kg} / \mathrm{ha}$ for crested wheat grass to a high of $6249 \mathrm{~kg} / \mathrm{ha}$ for intermediate wheat grass. The highest yielding grasses had the lower $6 D D M$. Reed canary grass had a rDDM of 53.9 and intermediate wheat grass a \%DDM of 57.2. Meadow foxtail, one of the lowest yielding species had the highest $r D D M$ of 72.2 . The yields of DDM ranged from 2374 to $3628 \mathrm{~kg} / \mathrm{ha}$. The highest DDM yield was for timothy which was followed closely by intermediate wheat grass. Crested wheat grass had the lowest DM and DDM yield.

Crude protein levels of the grass species ranged from $9.5 \%$ for intermediate wheat grass to $18.5 \%$ for meadow foxtail. Crested wheat grass had the second highest \%CP. All species, except intermediate wheat grass, had CP contents of $12 \%$ or higher. The highest CP yield was obtained from meadow foxtail because of its high $C P$ content and was followed closely by reed canary grass.

Average $P$ content of the grass species was $0.25 \%$. The lowest $P$ levels were for the wheat grasses, with $0.18 \%$ for intermediate wheat grass and $0.21 \%$ for crested wheat grass. The highest $P$ content of $0.33 \%$ was for meadow foxtail. The highest $\mathrm{Ca}$ level was for creeping red fescue with $0.43 \%$. All other species ranged from 0.26 to $0.37 \% \mathrm{Ca}$. Meadow foxtail had the 


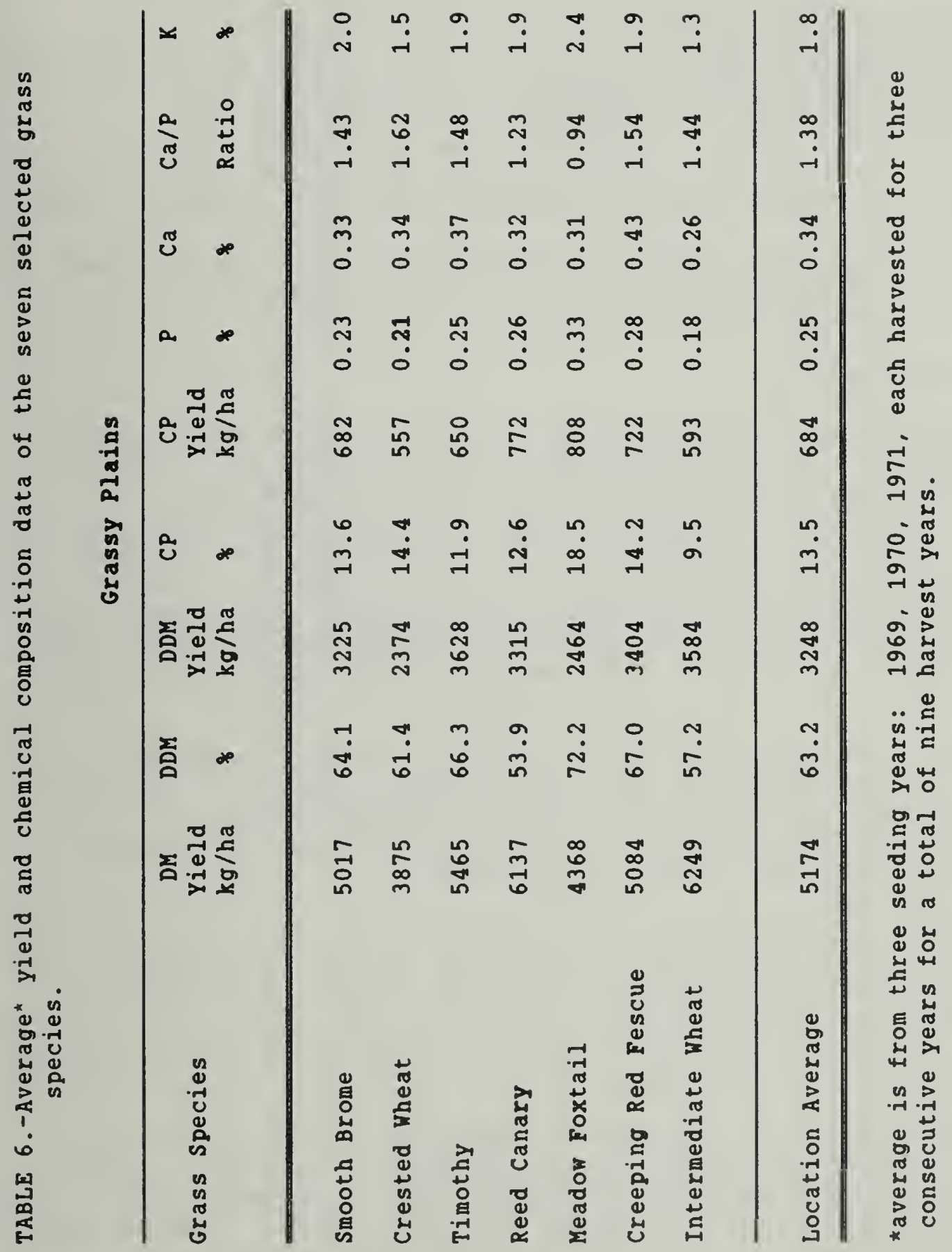


lowest $\mathrm{Ca} / \mathrm{P}$ ratio of 0.94 because of its high $\mathrm{P}$ uptake, while its Ca uptake was below average. The lowest level of $K$ was for the intermediate wheat grass species while the highest was in the meadow foxtail species. The average $\mathrm{K}$ content was below $2 \%$.

The micro-nutrient contents are not presented in a table. Magnesium contents ranged from 0.12 to $0.27 \%$ with an average of $0.18 \%$. Reed canary grass had the highest levels. Manganese level averaged $87.2 \mu \mathrm{g} / \mathrm{g}$. Creeping red fescue had the highest $\mathrm{Mn}$ content with $134.1 \mathrm{\mu g} / \mathrm{g}$. The average Cu levels were below $4 \mu \mathrm{g} / \mathrm{g}$ with a range of 2.6 to $4.4 \mu \mathrm{g} / \mathrm{g}$. Smooth brome grass and meadow foxtail had the highest $C u$ levels. Zinc levels ranged

from 22.6 to $41.3 \mu \mathrm{g} / \mathrm{g}$, with an average of 34.1 . The highest content was in crested wheat grass and the lowest in intermediate wheat grass.

\section{Vanderhoof (Table 7)}

The highest DM yield was obtained with intermediate wheat grass which yielded $5443 \mathrm{~kg} / \mathrm{ha}$ DM. Average yield of all seven grass species amounted to $4457 \mathrm{~kg} / \mathrm{ha}$ DM. The $6 D D M$ was relatively high for all species when compared to the other locations and ranged from 62.8 to $71.7 \%$. Smooth brome grass had the highest $6 D D M$ followed closely by meadow foxtail. Reed canary grass $\% D D M$ was the lowest, but was still over $60 \%$. The DDM yield showed that timothy gave the highest yield with 3494 $\mathrm{kg} / \mathrm{ha}$, followed closely by intermediate wheat grass with 3360 $\mathrm{kg} / \mathrm{ha}$.

Percent CP ranged from 10.8 to 16.5 . Intermediate wheat grass and timothy were the only two species below $13 \% \mathrm{CP}$. The highest $C P$ yield was obtained with reed canary grass.

Intermediate wheat grass and timothy, the highest DM yielders, had the lowest $\% C P$ but average $C P$ yields.

Phosphorus levels in the grass species ranged from 0.21 to $0.31 \%$, with the wheat grasses having the lowest and meadow foxtail the highest $P$ contents. Calcium levels had a similar trend, except that creeping red fescue had the highest Ca content. The Ca/P ratios were all very close to 1 as the Ca and $P$ levels were of the same magnitude.

The micro-nutrient levels are summarized in the following paragraph. Magnesium levels ranged from 0.12 to $0.26 \%$. Reed canary grass had the highest $M$ n content while crested wheat grass and intermediate wheat grass were the lowest. Manganese levels ranged from $14.1 \mu \mathrm{g} / \mathrm{g}$ for crested wheat grass to $52.1 \mu \mathrm{g} / \mathrm{g}$ for creeping red fescue. The $\mathrm{Cu}$ level of $2.8 \mathrm{\mu g} / \mathrm{g}$ for intermediate wheat grass was the lowest while smooth brome grass, with $5.2 \mu \mathrm{g} / \mathrm{g}$, was the highest. Average 


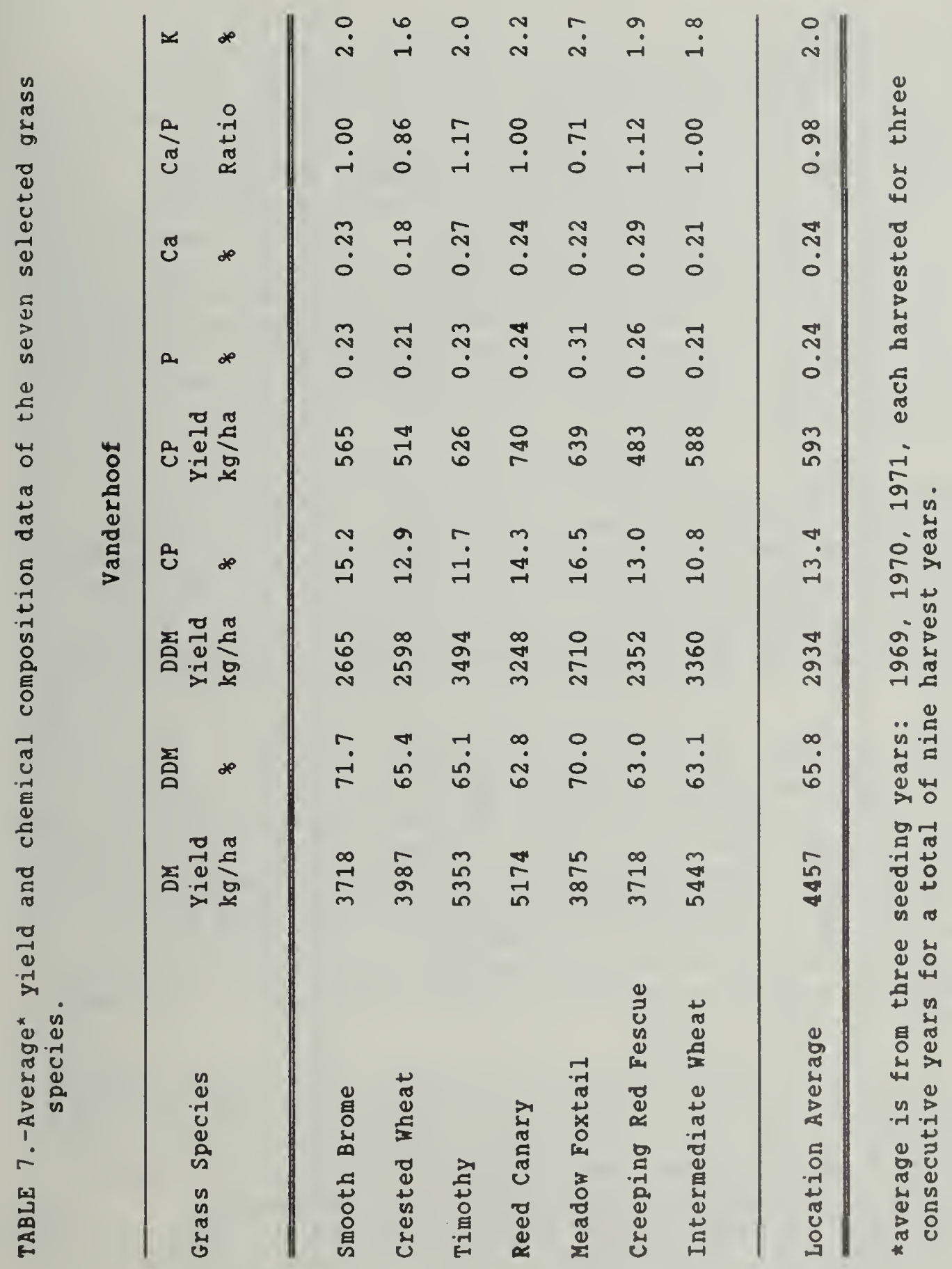


$\mathrm{Cu}$ content was $3.8 \mu \mathrm{g} / \mathrm{g}$. The range of $\mathrm{Zn}$ levels for the seven grass species was from a low of $13.3 \mathrm{\mu g} / \mathrm{g}$ for intermediate wheat grass to a high of $24.4 \mu \mathrm{g} / \mathrm{g}$ for meadow foxtail with an average of $18.3 \mathrm{\mu g} / \mathrm{g}$.

\section{Prince George(Table 8)}

Yields of DM ranged from 3516 to $7347 \mathrm{~kg} / \mathrm{ha}$ for the Prince George location. The highest yield was obtained with reed canary grass and was followed closely by smooth brome grass and timothy. The lowest yield, from crested wheat grass, was considerably lower than the next highest, meadow foxtail, with $4704 \mathrm{~kg} / \mathrm{ha}$. The $\% D D M$ for meadow foxtail, at $72.4 \%$, was more than $10 \%$ greater than crested wheat grass, at $61.9 \%$. The lowest \%DDM was for reed canary grass at 51.5\%. Determination of the DDM yield shows that the highest yield was obtained with smooth brome grass with $4278 \mathrm{~kg} / \mathrm{ha}$ and followed by timothy, $3875 \mathrm{~kg} / \mathrm{ha}$, and reed canary grass, $3785 \mathrm{~kg} / \mathrm{ha}$. Crested wheat grass had the lowest rDDM yield with $2172 \mathrm{~kg} / \mathrm{ha}$, at least $1100 \mathrm{~kg} / \mathrm{ha}$ lower than intermediate wheat grass.

The highest \%CP was obtained from meadow foxtail with 17.4\%. This was considerably more than crested wheat grass at $12.7 \%$, the next highest. Intermediate wheat grass was the only one below $10 \% \mathrm{CP}$. The $874 \mathrm{~kg} / \mathrm{ha}$ of CP from reed canary grass was the highest. Meadow foxtail, with $818 \mathrm{~kg} / \mathrm{ha}$ of $\mathrm{CP}$ was second highest, mainly because of its high \%CP. Crested wheat grass was at least $110 \mathrm{~kg} / \mathrm{ha}$ lower than intermediate wheat grass in CP yield.

Phosphorus content of the grass species averaged $0.24 \%$. The wheat grasses had the lowest levels, while meadow foxtail was the highest. The ca levels for all species, except creeping red fescue, were between 0.14 and $0.16 \%$. Creeping red fescue had a Ca content of $0.23 \%$. The Ca/P ratios of all species were below 1 because of the low Ca contents. The Ca/P ratio for meadow foxtail was the only one below 0.5 because of its high $P$ content. Meadow foxtail also had the highest $\mathrm{K}$ level at 3.0\%. All other species ranged between 1.5 and $2.2 \% \mathrm{~K}$, with the wheat grasses being the lowest.

The four micro-nutrient levels of $\mathrm{Mg}, \mathrm{Mn}, \mathrm{Cu}$, and $\mathrm{Zn}$ have been summarized, but are not presented in tabular form. The Mg content averaged $0.17 \%$, with reed canary grass having the highest at $0.24 \%$ and crested wheat grass the lowest at $0.12 \%$. The Mn level of creeping red fescue was the greatest at $185 \mu \mathrm{g} / \mathrm{g}$, followed by reed canary grass with $158.5 \mu \mathrm{g} / \mathrm{g}$. The overall average was $118.9 \mu \mathrm{g} / \mathrm{g}$. Copper levels averaged $4.8 \mu \mathrm{g} / \mathrm{g}$. Crested wheat grass and timothy, each with $3.8 \mathrm{\mu g} / \mathrm{g}$ of $\mathrm{Cu}$, were the lowest. Meadow foxtail, with 


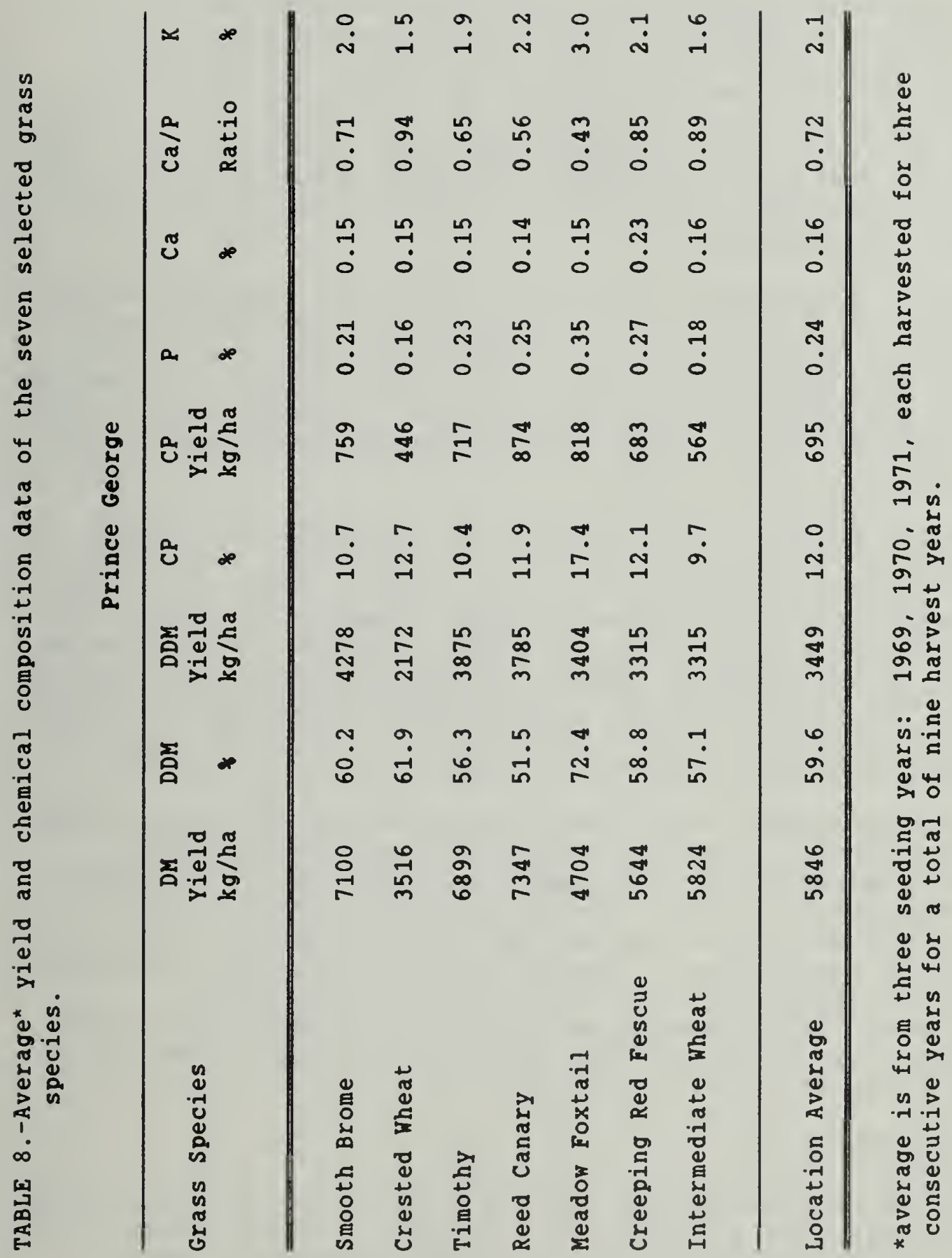


$7.9 \mu \mathrm{g} / \mathrm{g}$, was the highest. The $\mathrm{Zn}$ content ranged from 21.2 to $35.5 \mu \mathrm{g} / \mathrm{g}$ and averaged $29.0 \mu \mathrm{g} / \mathrm{g}$.

\section{McBride(Table 9)}

Yields of DM at MCBride were from 5331 to $8229 \mathrm{~kg} / \mathrm{ha}$. The top yield was obtained with intermediate wheat grass, and the lowest from meadow foxtail. Reed canary grass yielded 8064 $\mathrm{kg} / \mathrm{ha}$, which was followed by timothy at $7190 \mathrm{~kg} / \mathrm{ha}$. The $\%$ DDM ranged from $49.5 \%$ for reed canary grass, to a high of $67.2 \%$ for meadow foxtail. All other species had \%DDM between 55 and $62 \%$. Calculation of DDM yield resulted in intermediate wheat grass still having the highest DDM yield. Timothy and smooth brome grass were a little lower.

Percent CP levels were all higher than 10\%. Meadow foxtail had the highest $\% C P$ with 16.1. Creeping red fescue and smooth brome grass had CP contents of approximately 12\%, while the remainder of the species were just over 10\%. Even though meadow foxtail had the lowest yield, its high \%CP resulted in the best CP yield with $857 \mathrm{~kg} / \mathrm{ha}$. Intermediate wheat grass ranked second in yield with $854 \mathrm{~kg} / \mathrm{ha}$ of $\mathrm{DM}$.

Phosphorus content ranged from 0.17 to $0.33 \%$, with most species being between 0.17 and $0.20 \% \mathrm{P}$, except for creeping red fescue at $0.27 \%$, and meadow foxtail at $0.33 \%$. Calcium levels of the grass species were just over $0.20 \%$, except for timothy and creeping red fescue with 0.27 and $0.29 \%$, respectively. The Ca/P ratio of all grass species, except meadow foxtail, were between 1 and 1.5. The lower $\mathrm{Ca} / \mathrm{P}$ ratio of meadow foxtail is attributed to its high $\mathrm{P}$ content. Meadow foxtail had a $\mathrm{K}$ content of $3.3 \%$. The remaining species ranged in $\mathrm{K}$ levels from 1.8 to $2.3 \%$.

The micro-nutrient levels are not presented in tabular form but were summarized. The Mg content averaged $0.15 \%$, with crested wheat grass being the lowest at $0.10 \%$ and reed canary grass the highest at $0.18 \%$. The Mn levels varied from 22.7 to $79.5 \mathrm{\mu g} / \mathrm{g}$. The wheat grasses had the lowest content, and meadow foxtail the highest. Meadow foxtail also had the highest $\mathrm{Cu}$ level of $8.1 \mathrm{\mu g} / \mathrm{g}$ with all other species averaging $5.0 \mathrm{\mu g} / \mathrm{g}$ except for intermediate wheat grass which had a very low $\mathrm{Cu}$ content of $3.8 \mu \mathrm{g} / \mathrm{g}$. The $\mathrm{Zn}$ contents ranged from 19.9 to $35.9 \mu \mathrm{g} / \mathrm{g}$ and averaged $26.1 \mu \mathrm{g} / \mathrm{g}$.

\section{W1lllams Lake (Table 10)}

The yields of DM and some quality factors of the seven grass species are presented in Table 10. The grass species that were adapted to droughty conditions out-yielded the other grass species. Intermediate wheat grass yielded the most with 4704 $\mathrm{kg} / \mathrm{ha}$, and crested wheat grass was second with $3852 \mathrm{~kg} / \mathrm{ha}$. The 


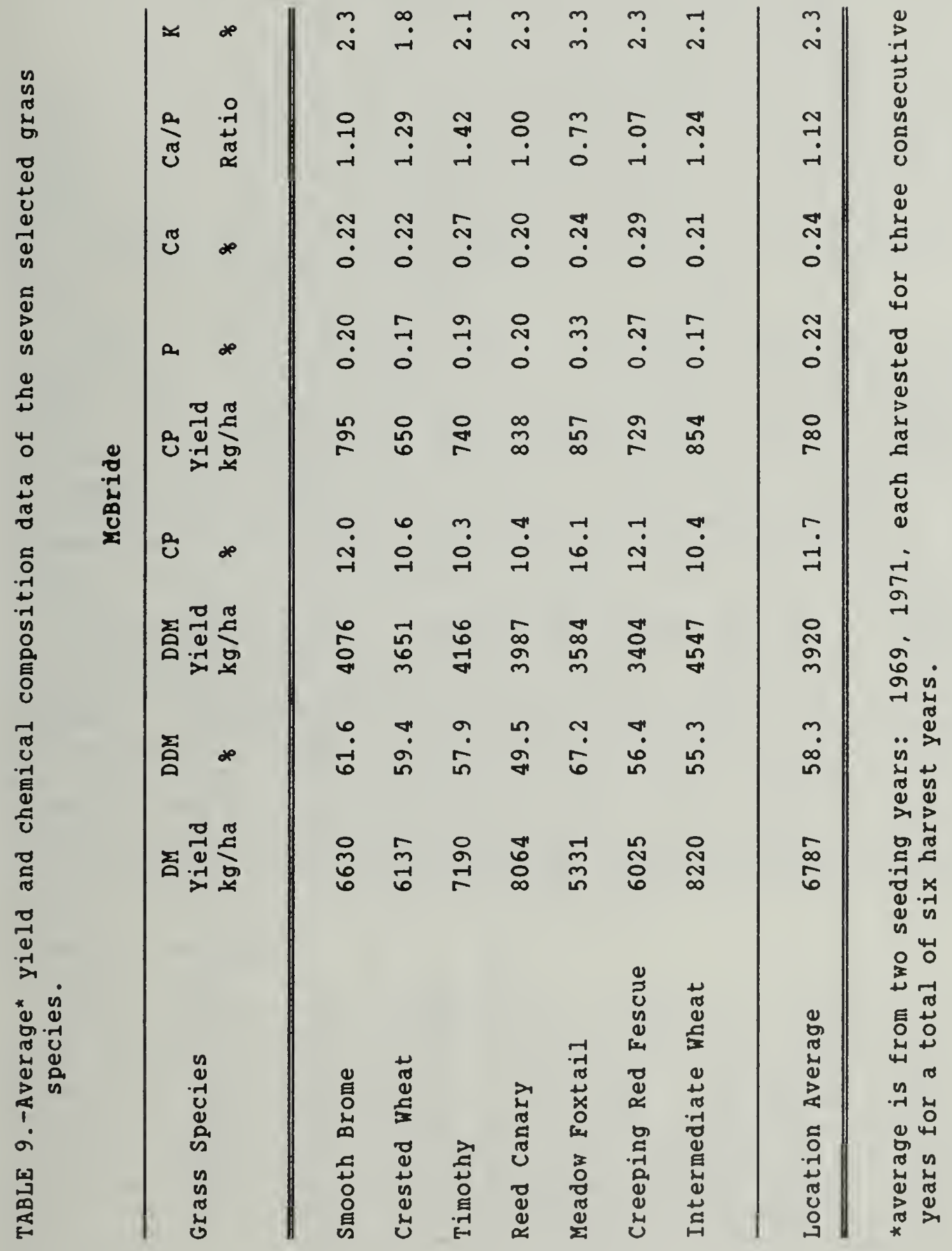




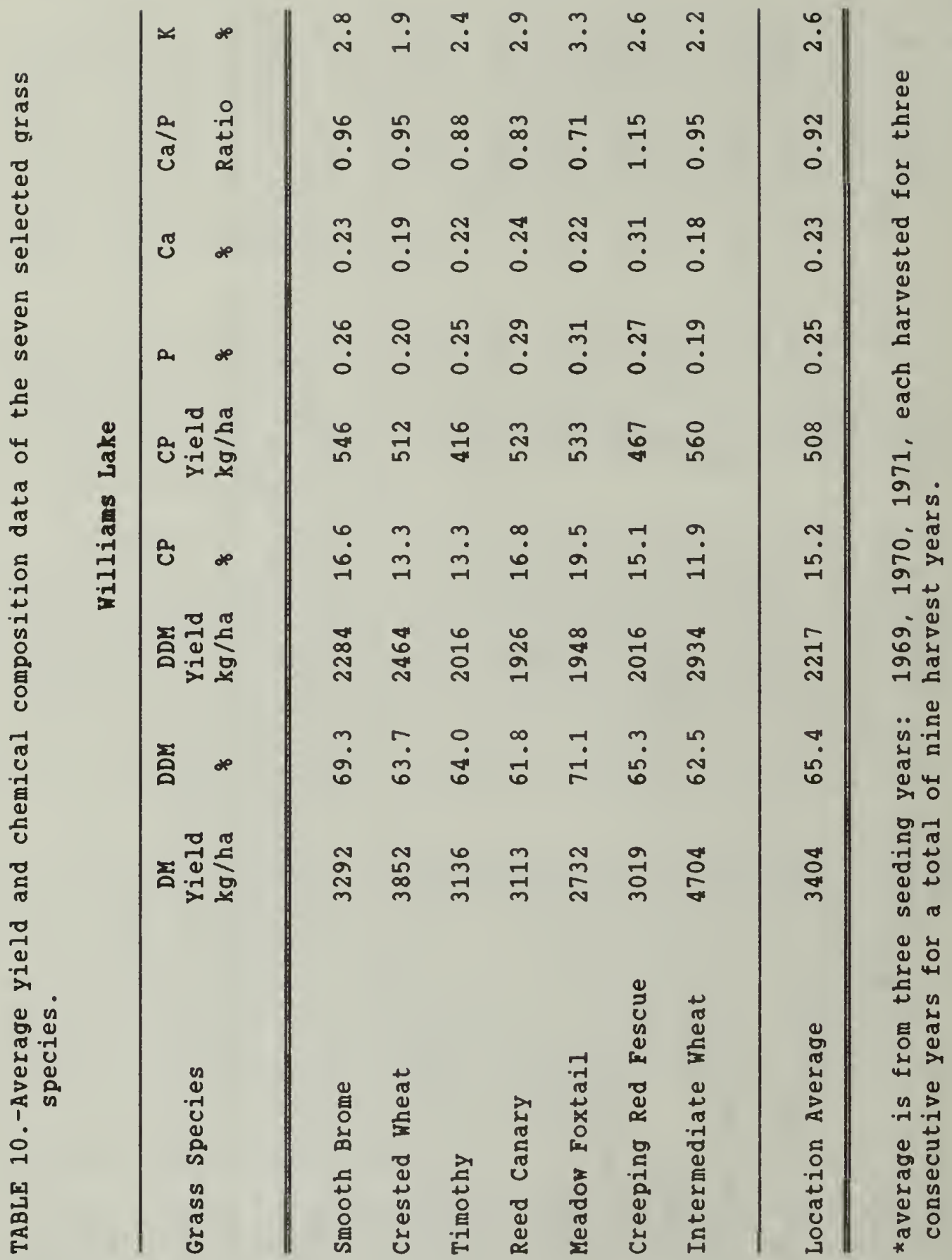


average DM yield of all grass species was $3404 \mathrm{~kg} / \mathrm{ha}$. The $8 D D M$ ranged from 61.8 to $71.1 \%$, with an average of $65.4 \%$. Meadow foxtail, with 71.1\%, and smooth brome grass, with 69.3\%, had the highest rDDM. Reed canary grass, at $61.8 \%$, was the lowest, but considerably higher than at other sites in Central B.C.

Percent $C P$ was high, with the overall average of $15.2 \%$. Meadow foxtail had close to $20 \% \mathrm{CP}$. The level of $\mathrm{CP}$ in the reed canary grass was $16.8 \%$, which was followed closely by smooth brome grass. The lowest $\%$ CP was for the intermediate wheat grass at 11.9\%. Even though intermediate wheat grass had the lowest $\% C P$, its CP yield was the highest at $560 \mathrm{~kg} / \mathrm{ha}$ because of its higher yield. Smooth brome grass was second with $546 \mathrm{~kg} / \mathrm{ha}$ CP. Meadow foxtail, the lowest yielding grass species, ranked third. The lowest CP yield was for timothy.

The $\mathbf{P}$ content of the grass species was the lowest for intermediate wheat grass, with $0.19 \%$ and crested wheat grass with $0.20 \%$. Meadow foxtail had the highest $\mathrm{P}$ concentration with $0.31 \%$. The range of $\mathrm{Ca}$ was narrow, from 0.18 to $0.24 \%$, except for creeping red fescue with $0.31 \%$. The Ca/P ratios were below 1 except for creeping red fescue, which had a higher Ca uptake level. The lowest Ca/P ratio was for meadow foxtail. Potassium concentration averaged 2.6\%. Crested wheat grass had the lowest level, with $1.9 \%$, and meadow foxtail with $3.3 \%$, the highest.

The micro-nutrient levels are summarized as follows. The level of $\mathrm{Mg}$ ranged from 0.15 to $0.26 \%$. The wheat grasses had the lowest concentration of $\mathrm{Mg}$, while reed canary grass had the highest. The Mn levels averaged $77.4 \mu \mathrm{g} / \mathrm{g}$. Creeping red fescue accumulated the most and crested wheat grass the least $\mathrm{Mn}$. The level of $\mathrm{Cu}$ averaged $4 \mathrm{\mu g} / \mathrm{g}$ with intermediate wheat grass, timothy, crested wheat grass, and creeping red fescue all being below the average. The $\mathrm{Zn}$ content ranged from 19.2 to $34.2 \mathrm{\mu g} / \mathrm{g}$, with all grass species, except intermediate wheat grass, being very close to the maximum.

\section{Location Averages}

The yields of DM at the seven different locations varied with the amount of precipitation available, temperature, and the soil conditions (Table 11). The lower the precipitation and the higher the mean temperature, the lower was the DM yield. The Williams Lake location had the lowest yield because of the greatest summer water deficit. The smithers \#1 and McBride locations had higher yields because of the lighter textured soils that warm up more quickly in the spring and allow better root penetration and water use. Soils, such as the clays at Prince George, are cold in the spring and plant roots do not penetrate deeply. 


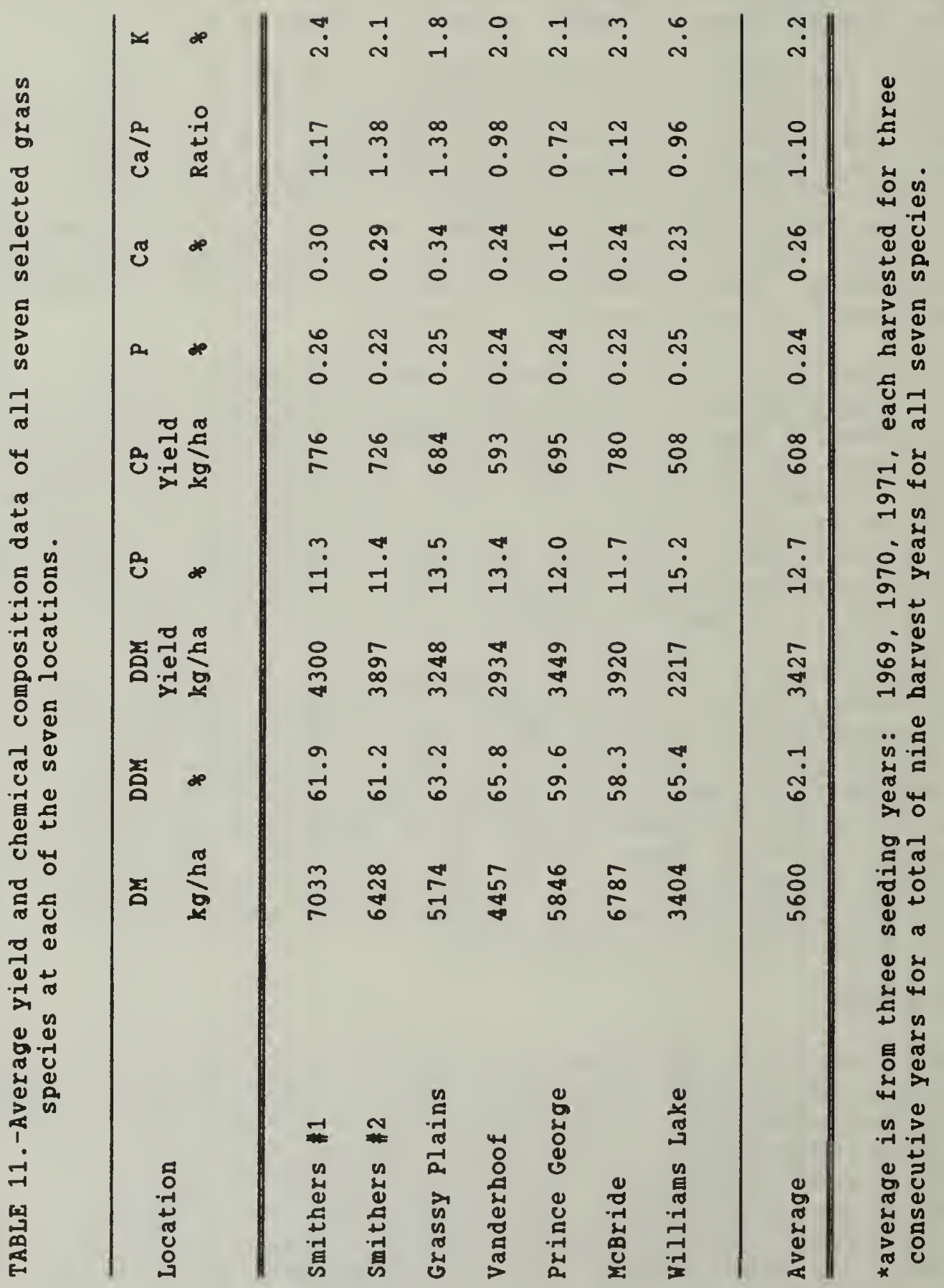


The $6 D D M$ ranged from $58.3 \%$ at McBride to $65.8 \%$ at Vanderhoof. Locations receiving the lower precipitation had the higher $6 D D M$ because the plants matured more rapidly. The yield of DDM generally followed the trend of DM yield. The rCP for the three drier sites, Grassy Plains, Vanderhoof and Williams Lake, were the highest and followed the same ranking as \%DDM. These three sites had an average $\% C P$ of over $13 \%$. The remaining locations ranged from 11.3 to $12.0 \%$. Yield of CP had the same ranking as the yield DM except that the Smithers \#1 and McBride location rankings were reversed.

Levels of $P$ were on average above $0.20 \%$ at each site. Calcium levels were the lowest at Prince George at $0.16 \%$, where the soil is more leached and has the lowest pH. All other sites had mean Ca levels of over $0.23 \%$. The ratio of $\mathrm{Ca} / \mathrm{P}$ is as important as the actual level of each element for animal nutrition. Cattle require a ratio of between 1:1 to $7: 1$. The $\mathrm{K}$ levels were more than adequate at all sites.

Micro-nutrient levels for the seven locations are summarized in Table 13. Magnesium levels ranged from 0.11 to $0.19 \%$, with the drier sites generally having a higher Mg content. These levels are more than adequate for cattle nutrition. Similarly, the Mn requirements of cattle should have been met by the forage grown at each location. Levels of copper, were either marginally adequate or below the requirements of cattle, $4 \mathrm{\mu g} / \mathrm{g}$. Beef cattle require between 10 and $30 \mu \mathrm{g} / \mathrm{g} \mathrm{Zn}$ on a dry matter basis. The lowest $\mathrm{Zn}$ levels were found at Vanderhoof with $18.3 \mu \mathrm{g} / \mathrm{g}$. All other sites were between 23 and $35 \mu \mathrm{g} / \mathrm{g} \mathrm{Zn}$.

\section{species Averages}

The species averages for yield, \%DDM, \%CP, and macronutrients, as well as some of their calculated paramenters are found in Table 12, and the micro-nutrient levels in Table 13. It must be remembered that the species averages cover locations with varying climatic conditions, ranging in moisture availability and temperature as demonstrated by the climatic data in Table 3 .

The highest average yield for all sites was obtained with reed canary grass, which also had the highest yield of CP. It had the lowest $6 D D M$, which declines rapidly with increasing maturity. For this reason, reed canary grass should be cut at the late boot stage to obtain forage with the highest possible digestibility. When growing reed canary grass, low alkaloid varieties such as Vantage should be used. Although intermediate wheat grass produced the second highest yield of DM this species 


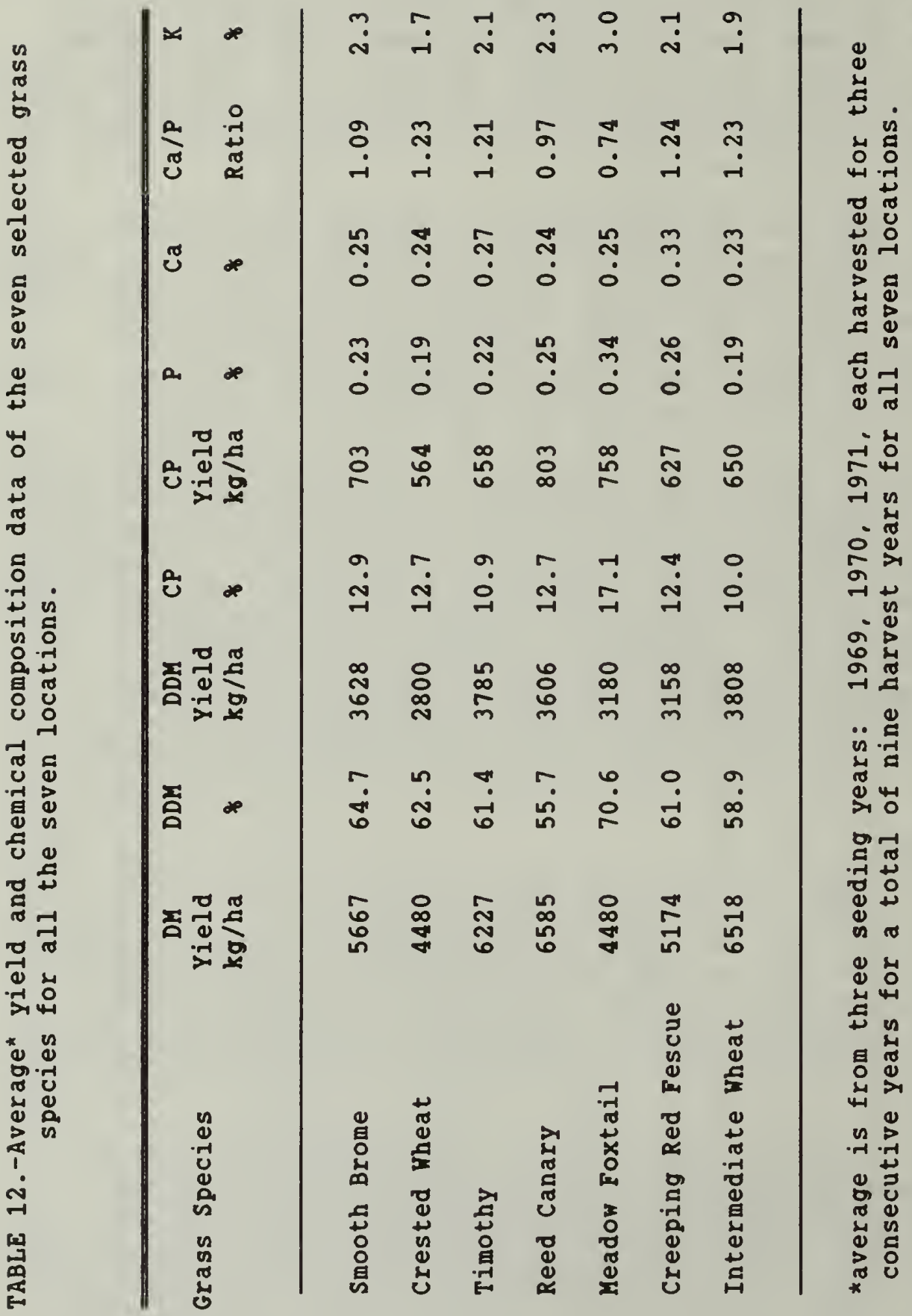


TABLE 13. - The average content of $\mathrm{Mg}, \mathrm{Mn}, \mathrm{Cu}$, and $\mathrm{Zn}$ for the seven selected grass species and for the seven locations.

\begin{tabular}{lcccc}
\hline GRASS SPECIES & $\begin{array}{c}\mathrm{Mg} \\
\%\end{array}$ & $\begin{array}{c}\mathrm{Mn} \\
\mu \mathrm{g} / \mathrm{g}\end{array}$ & $\begin{array}{c}\mathrm{Cu} \\
\mu \mathrm{g} / \mathrm{g}\end{array}$ & $\begin{array}{c}\mathrm{Zn} \\
\mu \mathrm{g} / \mathrm{g}\end{array}$ \\
\hline Smooth Brome & 0.14 & 57.6 & 5.5 & 25.9 \\
Crested Wheat & 0.11 & 36.8 & 3.7 & 28.4 \\
Timothy & 0.15 & 46.6 & 3.5 & 27.9 \\
Reed Canary & 0.22 & 73.3 & 4.1 & 28.8 \\
Meadow Foxtail & 0.17 & 79.2 & 5.9 & 35.2 \\
Creeping Red Fescue & 0.17 & 101.6 & 4.3 & 25.1 \\
Intermediate Wheat & 0.13 & 48.3 & 3.0 & 19.4 \\
\hline
\end{tabular}

\begin{tabular}{lcccc}
\hline LOCATION & $\begin{array}{c}\text { Mg } \\
\%\end{array}$ & $\begin{array}{c}\text { Mn } \\
\mu g / g\end{array}$ & $\begin{array}{c}\mathrm{Cu} \\
\mu \mathrm{g} / \mathrm{g}\end{array}$ & $\begin{array}{c}\mathrm{Zn} \\
\mu \mathrm{g} / \mathrm{g}\end{array}$ \\
\hline Smithers \#1 & 0.11 & 56.3 & 3.9 & 29.7 \\
Smithers \#2 & 0.13 & 28.1 & 4.9 & 23.6 \\
Grassy Plains & 0.18 & 87.2 & 3.5 & 34.1 \\
Vanderhoof & 0.19 & 30.7 & 3.8 & 18.3 \\
Prince George & 0.17 & 117.1 & 4.8 & 29.4 \\
McBride & 0.15 & 46.5 & 5.3 & 26.1 \\
Williams Lake & 0.19 & 77.4 & 4.0 & 29.5 \\
\hline
\end{tabular}


was not highly digestible either and had a low CP content compared to the other species. The actual DDM yield for intermediate wheat grass, timothy, smooth brome grass and reed canary grass were similar. In spite of low yields meadow foxtail, could have a special use for early pasture or hay because it matures 2 to 3 weeks earlier than the other grass species and has good regrowth potential. However, feeding and grazing trials at the Prince George Experimental Farm have shown timothy to be highly superior to meadow foxtail.

The macro-nutrient content for the different species showed consistent quality differences. Crested and intermediate wheat grasses contained the lowest $P$ content, while meadow foxtail had the highest. Smooth brome grass, timothy, reed canary grass, and creeping red fescue were near average. Calcium content of all grass species was similar, except for creeping red fescue which had the highest $\mathrm{Ca}$ content. The Ca/P ratio of each species reflects its $\mathrm{Ca}$ and $\mathrm{P}$ uptake. This ratio was lower for meadow foxtail because of its higher affinity for $P$; and the highest for wheat grasses, because they had the lowest $P$ uptake. In all species, except meadow foxtail, the Ca/p ratio was between $1: 1$ and $2: 1$, which is adequate for cattle rations. Meadow foxtail diets require $\mathrm{Ca}$ supplementation to bring the $\mathrm{Ca} / \mathrm{P}$ ratio to a value greater than 1 . Forages usually contain sufficient $\mathbb{K}$ to meet the requirements of beef cattle. In this experiment, the plant contents of 1.7 to $3.0 \%$ were 2 to 3 times the requirement of 0.6 to $0.8 \% \mathrm{~K}$. The highest plant uptake of $\mathrm{K}$ was by meadow foxtail, while the lowest was by crested and intermediate wheat grasses.

The micro-nutrient contents of the different species show considerable differences. The wheat grasses had the lowest levels of $\mathrm{Mg}$ and $\mathrm{Mn}$ of all species tested. Intermediate wheat grass also had the lowest $\mathrm{Cu}$ and $\mathrm{Zn}$ contents. Reed canary grass contained the highest Mg levels, while creeping red fescue had the highest $\mathrm{Mn}$ content. The levels of $\mathrm{Cu}$ and $\mathrm{Zn}$ were the highest in meadow foxtail. The level of $\mathrm{Cu}$ was close to that required for animal nutrition, and could become deficient if forage contained high levels of molybdenum(Mo) or sufates $\left(\mathrm{SO}_{4}^{-2}\right)$. All other micro-nutrients analyzed for were adequate for cattle production.

\section{SUMMARY AND CONCLUSIONS}

At the Smithers \#1 site the best yield was obtained with reed canary grass, timothy, intermediate wheat grass, and smooth brome grass. The $\% D D M$ of reed canary grass was very low, while its $r C P$ was the poorest of all the species in the test. Timothy had the second highest $\% D D M$ but also had a low $\% C P$ content. Intermediate wheat grass had both low $\% D D M$ and $\% C P$. Smooth 
brome grass gave an intermediate yield of better than average quality grass.

The best yielding species at the smithers \#2 location were reed canary grass, timothy, and intermediate wheat grass. The reed canary grass had moderate $\% C P$ levels while the quality of both the other grasses was low.

Of the seven grass species grown at Grassy Plains the best yielding species were intermediate wheat grass and reed canary grass. Both these species had the lowest $\$ D D M$. The $\% C P$ level of intermediate wheat grass was considerably lower than the other species at $9.5 \%$ while the overall $\%$ CP average was $13.5 \%$.

At Vanderhoof, the intermediate wheat grass, timothy, and reed canary grass were the top yielding species. Intermediate wheat grass had the lowest $\% C P$ of all grass species grown, while reed canary grass was above the average. The \%DDM of reed canary grass was very low, while that of intermediate wheat grass was average. Timothy, the second highest yielding grass species had a low $\% C P$ and an average $\% D D M$.

The highest yielding grass species at the Prince George location were reed canary grass, smooth brome grass, and timothy. Reed canary grass had the lowest \$DDM, but all other quality factors were about average for the top three yielders.

Intermediate wheat grass had the highest yield, followed closely by reed canary grass at McBride. The quality of intermediate wheat grass compared to the other grass species was one of the poorest. Reed canary grass had an average $\% C P$ content with the lowest $6 D D M$ of all the grass species at this location.

At the Williams Lake location, intermediate wheat grass and crested wheat grass had the highest yield. The quality factors of these two grass species were near the lowest of all the species tested at this location.

Intermediate wheat grass had the highest $\% D M$ yield at four of the seven locations. Reed canary grass was the top yielding grass at the three remaining locations, Smithers \#1, Smithers \#2 and Prince George. Timothy ranked second or third at all locations except Williams Lake where it ranked fourth. The lower yielding grass species were crested wheat grass, meadow foxtail and creeping red fescue. At the Williams Lake site the species more suited to drier soil conditions, intermediate wheat grass, crested wheat grass and smooth brome did extremely well (Appendix C1). 
In vivo \%DDM was the highest for meadow foxtail at all locations except at Vanderhoof, where smooth brome grass was best. Reed canary grass had a consistent low \%DDM. The \%DDM for intermediate wheat grass was one of the poorest at all locations. The \%DDM for smooth brome grass, crested wheat grass, timothy and creeping red fescue varied with each location (Appendix C2).

The $\% C P$ for meadow foxtail was the highest at all locations. Intermediate wheat grass had the lowest $\% C P$ at all locations, except McBride where it was timothy. Timothy, on the otherhand, had the second lowest $\% \mathrm{CP}$ at all locations, except McBride. The remaining grass species varied considerably with location (Appendix C3).

The concentration of $P$ in meadow foxtail was the highest but the lowest for the wheat grasses. Creeping red fescue accumulated a higher concentration of $\mathrm{Ca}$ than the other grass species tested. The $\mathrm{Ca} / \mathrm{P}$ ratio of meadow foxtail was always well below 1 and requires $C a$ supplementation when fed to cattle (Table 12).

Micro-nutrient levels also varied with grass species. The wheat grasses tended to be low in comparison to the other species grown in $\mathrm{Mg}, \mathrm{Mn}, \mathrm{Cu}$ and $\mathrm{Zn}$. Reed canary grass accumulates higher amounts of $\mathrm{Mg}$ and creeping red fescue greater concentrations of Mn. Meadow foxtail consistently had the highest levels of $\mathrm{Cu}$ and $\mathrm{Zn}$ (Table 13). 
APPENDIX A. Notations used

$\begin{array}{ll}\text { Ca } & \text { Calcium } \\ \text { Cu } & \text { Copper } \\ \mathrm{CP} & \text { Crude protein } \\ \mathrm{CP} \text { yield } & \text { Crude protein yield } \\ \mathrm{DDM} & \text { Digestible dry matter } \\ \mathrm{DDM} \text { yield } & \text { Digestible dry matter yield (DM yield x \%DDM) } \\ \mathrm{DM} & \text { Dry matter } \\ \mathrm{DM} \text { yield } & \text { dry matter yield } \\ \mathrm{g} & \text { gram } \\ \mathrm{ha} & \text { hectare } \\ \text { in vivo } & \text { pertaining to a biological reaction taking place } \\ \mathrm{K} & \text { in a living cell or organism. } \\ \mathrm{K}_{2} \mathrm{O}^{*} & \text { potassium } \\ \mathrm{kg} & \text { potashor potassium oxide } \\ \mathrm{kg} / \mathrm{ha} & \text { kilograms } \\ \mathrm{km} & \text { kilometers } \\ \mathrm{m} & \text { meter } \\ \mathrm{mm} & \text { millimeter } \\ \mathrm{Mg} & \text { mangnesium } \\ \mathrm{Mo} & \text { molybdenum } \\ \mathrm{N} & \text { nitrogen } \\ \mathrm{P} & \text { phosphorus } \\ \mathrm{P}_{2} \mathrm{O}_{5} * * & \text { phosphoric acid or phosphorus oxide. } \\ \mathrm{S} & \text { sulfur } \\ \mathrm{SO}{ }_{4}-2 & \text { sulphate } \\ \mathrm{ug} / \mathrm{g} & \text { microgram per gram (10-6 gram per gram) } \\ \mathrm{Zn} & \text { zinc }\end{array}$

* potash - the term that refers to the potassium content of a fertilizer.

** phosphoric acid - a term that refers to the phosphorus content of a fertilizer. 
APPENDIX B. Conversion Factors for English and Metric Units

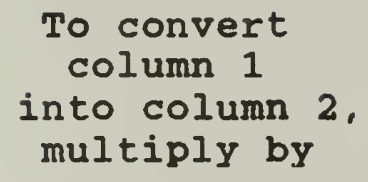

To convert column 2 into comunm 1 multiply by

\section{Length}

0.621

1.094

0.394

2.471

1.102

2.205

0.892 kilometer, km meter, $m$ centimeter, cm mile, mi yard, yd

inch, in

Area

acre, A

0.405

Mass ton (metric) kilogram,kg

ton (English) pound, Ib

0.9072

0.454

1.609

0.914

2.540

Yield

ton (metric)/ha $\mathrm{kg} / \mathrm{ha}$ ton (English)/A

lb/acre 


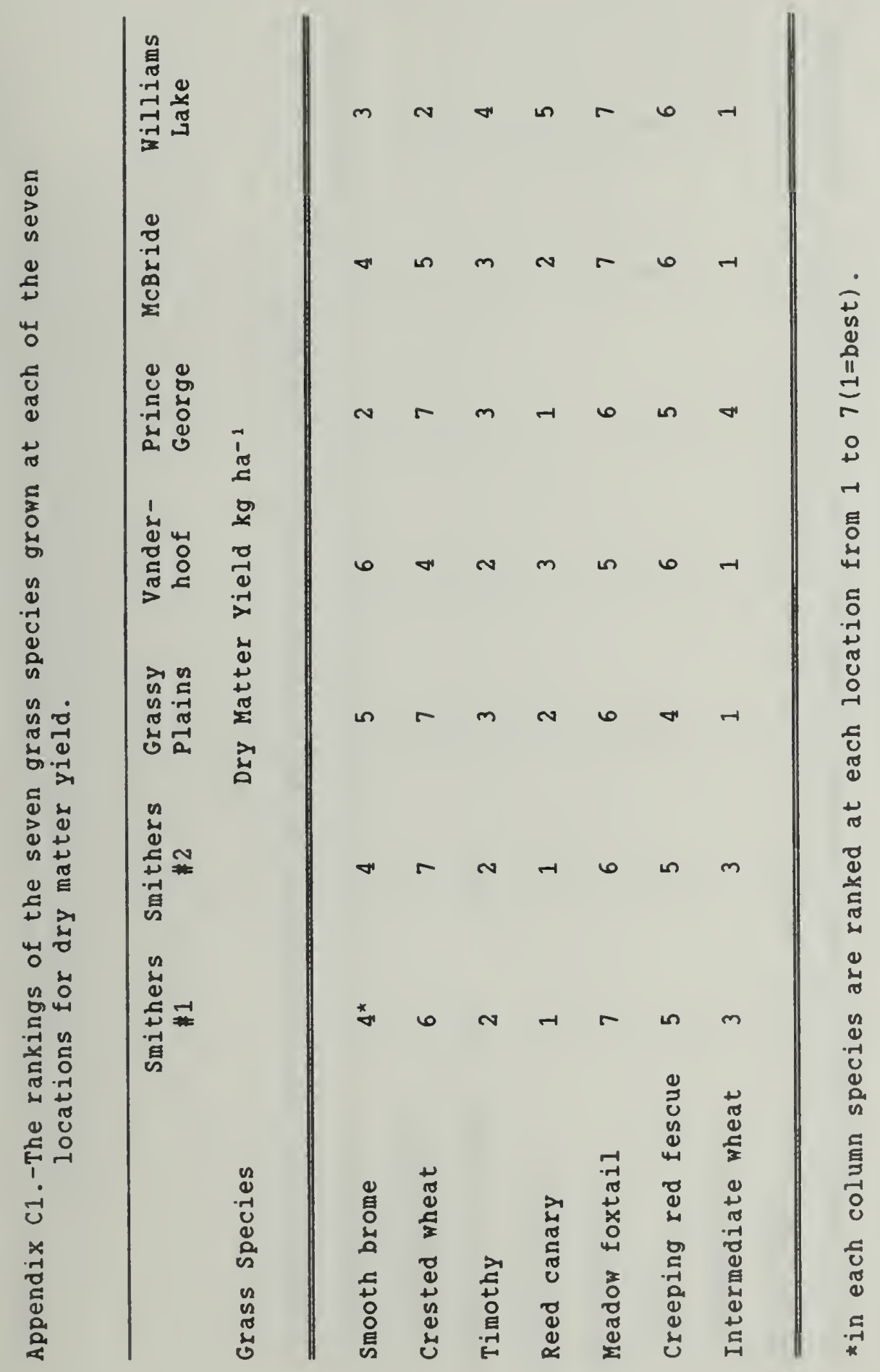




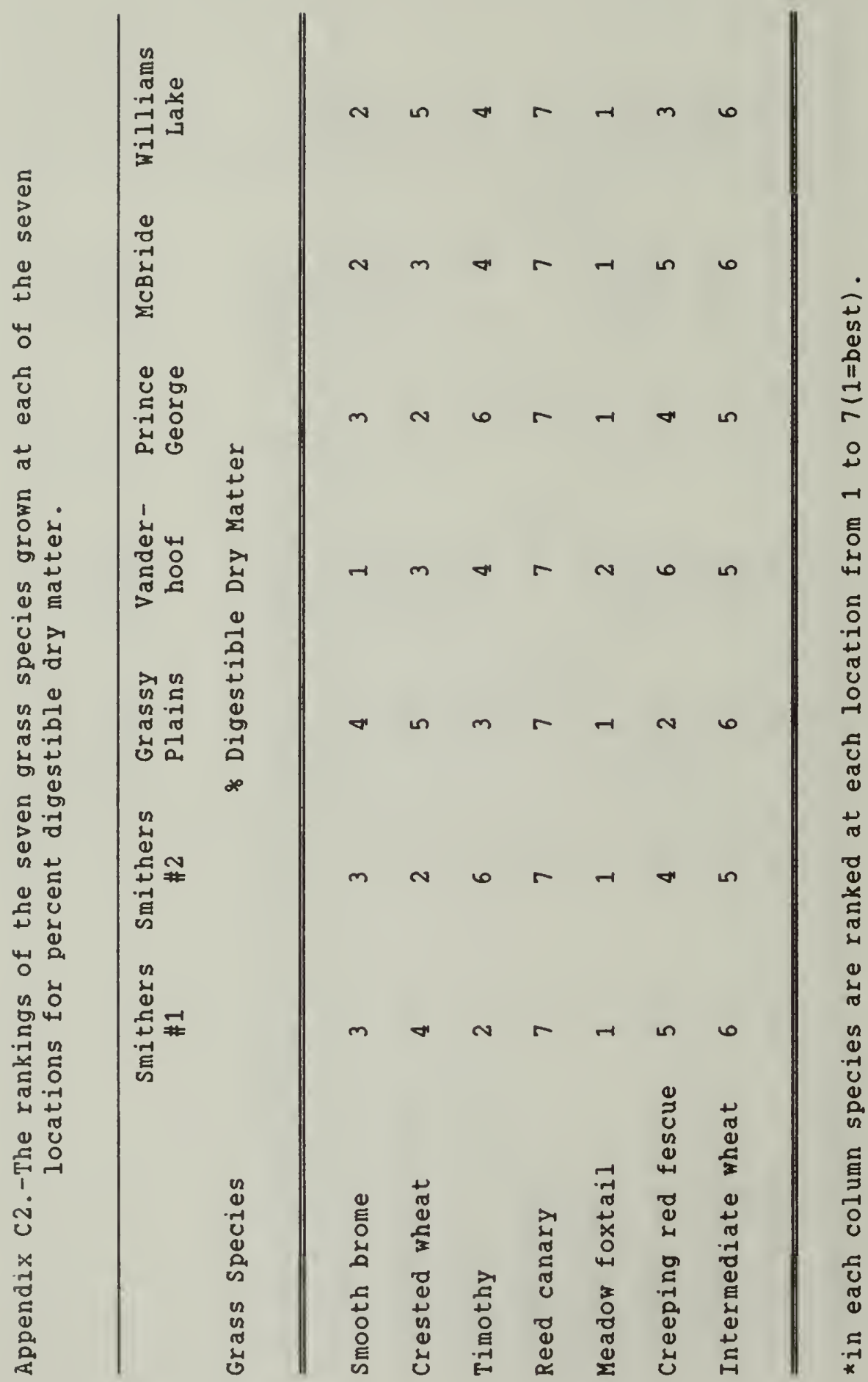




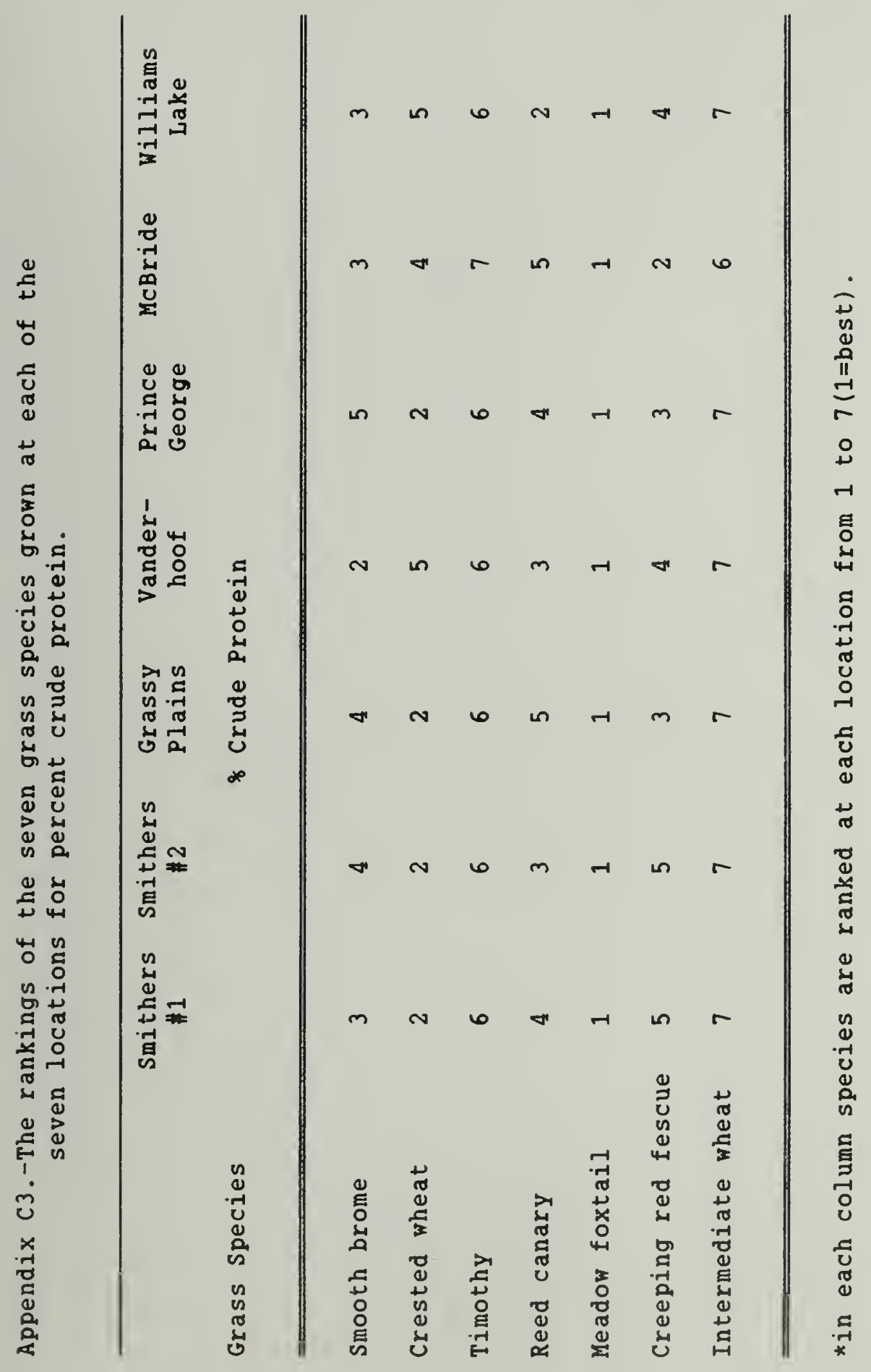



